\title{
Phenotypic Screening of Chemical Libraries Enriched by Molecular Docking to Multiple Targets Selected from Glioblastoma Genomic Data
}

\author{
David $\mathrm{Xu}^{2,3 \dagger}$, Donghui Zhou ${ }^{1 \dagger}$, Khuchtumur Bum-Erdene ${ }^{1}$, Barbara J. Bailey, ${ }^{4,5,6}$, \\ Kamakshi Sishtla ${ }^{8}$, Sheng Liü ${ }^{2,7}$, Jun Wan²,7, Uma K. Aryal ${ }^{9}$, Jonathan A. Lee ${ }^{1}$, \\ Clark D. Wells ${ }^{1}$, Melissa L. Fishel ${ }^{4,5,6}$, Timothy W. Corson ${ }^{1,5,6,8}$, Karen E. \\ Pollok ${ }^{4,5,6 *}$, and Samy O. Meroueh ${ }^{1,2,6 *}$
}

${ }^{1}$ Department of Biochemistry and Molecular Biology, Indiana University School of Medicine, Indianapolis, IN 46202 ${ }^{2}$ Center for Computational Biology and Bioinformatics, Indiana University School of Medicine, Indianapolis, IN 46202 ${ }^{3}$ Department of BioHealth Informatics, Indiana University School of Informatics and Computing, Indianapolis, IN 46202 ${ }^{4}$ Department of Pediatrics, Herman B. Wells Center for Pediatric Research, Indiana University School of Medicine, Indianapolis, IN 46202

${ }^{5}$ Department of Pharmacology and Toxicology, Indiana University School of Medicine, Indianapolis, IN 46202

${ }^{6}$ Indiana University Melvin and Bren Simon Cancer Center, Indiana University School of Medicine, Indianapolis, IN 46202

${ }^{7}$ Department of Medical and Molecular Genetics, Indiana University School of Medicine, Indianapolis, IN 46202

${ }^{8}$ Eugene and Marilyn Glick Eye Institute, Department of Ophthalmology, Indiana University School of Medicine, Indianapolis, IN 46202

${ }^{9}$ Purdue Proteomics Facility, Bindley Bioscience Center, Purdue University, West Lafayette, IN 47907

${ }^{*}$ Corresponding authors

${ }^{\dagger}$ Authors contributed equally

\section{Corresponding Authors: Samy Meroueh}

Department of Biochemistry and Molecular Biology

Indiana University School of Medicine

635 Barnhill Drive, MS4021

Indianapolis, IN 46202

Tel: (317) 274-8315

E-mail: smeroueh@iu.edu

\author{
Karen Pollok \\ Department of Pediatrics \\ Indiana University School of Medicine \\ 1044 W Walnut St, Indianapolis, IN 46202, R4 302 \\ Indianapolis, IN 46202 \\ Tel: (317) 274-8891 \\ E-mail: kpollok@iu.edu
}

This is the author's manuscript of the article published in final edited form as:

Xu, D., Zhou, D., Bum-Erdene, K., Bailey, B. J., Sishtla, K., Liu, S., Wan, J., Aryal, U. K., Lee, J. A., Wells, C. D., Fishel, M. L., Corson, T. W., Pollok, K., \& Meroueh, S. O. (2020). Phenotypic Screening of Chemical Libraries Enriched by Molecular Docking to Multiple Targets Selected from Glioblastoma Genomic Data. ACS Chemical Biology. https://doi.org/10.1021/acschembio.0c00078 


\begin{abstract}
Like most solid tumors, glioblastoma multiforme (GBM) harbors multiple overexpressed and mutated genes that affect several signaling pathways. Suppressing tumor growth of solid tumors like GBM without toxicity may be achieved by small molecules that selectively modulate a collection of targets across different signaling pathways, also known as selective polypharmacology. Phenotypic screening can be an effective method to uncover such compounds, but the lack of approaches to create focused libraries tailored to tumor targets has limited its impact. Here, we create rational libraries for phenotypic screening by structure-based molecular docking chemical libraries to GBM-specific targets identified using the tumor's RNAseq and mutation data along with cellular protein-protein interaction data. Screening of this enriched library of 50 candidates led to several active compounds. Among them 1 (IPR-2025), which (i) inhibited cell viability of low-passage patient-derived GBM spheroids with single-digit micromolar $\mathrm{IC}_{50} \mathrm{~S}$ that are substantially better than standard-of-care temozolomide; (ii) blocked tube-formation of endothelial cells in Matrigel with sub-micromolar $\mathrm{IC}_{50} \mathrm{~s}$; and (iii) had no effect on primary hematopoietic $\mathrm{CD} 4^{+}$progenitor spheroids or astrocyte cell viability. RNA sequencing (RNA-seq) provided potential mechanism of action of 1 and mass spectrometry-based thermal proteome profiling (TPP) confirmed that the compound engages multiple targets. The ability of 1 to inhibit GBM phenotypes without affecting normal cell viability suggests that our screening approach may hold promise for generating lead compounds with selective polypharmacology for the development of treatments of incurable diseases like GBM.
\end{abstract}




\section{INTRODUCTION}

Like most solid incurable tumors, glioblastoma multiforme (GBM) exhibit multiple hallmarks of cancer as delineated by Hanahan and Weinberg(1): Self-sufficiency in growth signals, insensitivity to growth inhibitory signals, evasion from programmed cell death (apoptosis), ability to undergo limitless cycles of cell growth, sustained ability to be supplied by blood (angiogenesis), and aggressive invasion of the brain parenchyma. Large-scale sequencing studies of human tumors such as The Cancer Genome Atlas (TCGA) project have revealed that the complex phenotypes that define cancer are driven by a large number of somatic mutations that occur in proteins across the cellular network(2). Whole genome sequencing studies that have profiled the molecular signatures of various cancers, such as in ovarian(3), colorectal(4), breast(5), renal(6), lung(7-9), pancreatic $(10,11)$, and brain $(12,13)$, have further confirmed that the complex phenotypes are driven by multiple targets spanning interconnected signaling pathways across the human protein-protein interaction network.

Suppressing the growth and metastasis of solid tumors harboring tens of mutations without causing toxicity will require small molecules that selectively modulate multiple targets and signaling pathways. The identification of such compounds is a significant challenge, as most drugs that target multiple proteins are discovered in a retrospective manner. In some cases, drugs are developed to inhibit one target, but later, they are found to have additional targets(14). Metformin is one example of a drug that was developed to treat diabetes, but was later found to have beneficial effects in cancer likely due to off-targets of the drug(15). Drugs that were discovered either from natural products or phenotypic screens also often work through polypharmacology. One example is aspirin, which not only inhibits cyclooxygenases but also neutrophil activation and inducible nitric acid synthesis(16).

There has been a resurgence of interest in phenotypic screening in cancer drug discovery(17). Between 1999 and 2008, over half of FDA-approved first-in-class small-molecule drugs were discovered through phenotypic screening(18). The increased interest in phenotypic screening is due in part to the lack of effective treatment options for incurable tumors such as GBM, which remains the most aggressive brain tumor and responds poorly to standard-of-care therapy that includes surgery, irradiation, and temozolomide. Standard-of-care therapies for GBM have been essentially unchanged for decades with a median survival of only 14-16 months and a five-year survival rate of 3-5\%(19,20). Ineffective tumor cell killing is largely due to intra-tumoral genetic instability which allows these malignancies to modulate cell survival pathways, angiogenesis, and invasion(21,22). In addition, the highly immunosuppressive GBM 
microenvironment complicates therapeutic approaches that minimize tumor burden and promote host immunity(23-25). Moreover, investigations to date indicate therapies that combine TMZ with immunotherapy-based approaches can either promote or deplete immunity(26-29). Phenotypic screening can be an effective strategy for the development of small molecules to perturb the function of proteins that drive tumor growth and invasion. Despite the increased interest in phenotypic screening in cancer drug discovery, the main limitations of the approach include (i) the lack of methods to tailor library selection to the tumor genome, (ii) cellular assays that do not accurately represent a tumor, (iii) overreliance on immortalized cell lines, (iv) targeting a single protein when tumors are driven by multiple proteins, and $(v)$ confining compound screening to one phenotype.

To date, most phenotypic screens are carried out on well-annotated tool compound libraries that include FDA-approved drugs. These are known as chemogenomic libraries, and they are used to uncover new biology for targets associated with these compounds or for drugrepurposing purposes(30-33). However, existing approved drugs and tool compounds act on less than $5 \%$ of targets in the human genome(34). The lack of target diversity in chemogenomic libraries presents an opportunity for the development of new chemical libraries or for the enrichment of existing libraries. The creation of diverse libraries for high-throughput screening is a major challenge considering the vastness of chemical space. Just among commerciallyavailable compounds, there are now at least 400 million small organic compounds that can be purchased(35,36). In addition, specialized libraries designed using diversity-oriented synthesis (DOS)(37) and de novo combinatorial libraries such as SCUBIDOO(38) offer additional avenues to screen unexplored chemical space.

Traditional two-dimensional monolayer assays utilizing cancer cell lines have been the most practical method to phenotypically screen these large libraries. However, these screening campaigns have yielded compounds that fail to model compound efficacy and cytotoxicity in more disease-relevant assays(39). Traditional two-dimensional assays do not accurately capture the three-dimensional microenvironment of tumors, thus leading to toxic compounds that generally tend to block microtubule dynamics or lead to DNA modification $(40,41)$. The use of immortalized cell lines to predict efficacy is now also recognized to be inadequate(42). There are now many examples of small molecules that are efficacious in traditional in vitro and in vivo models yet fail to show clinical efficacy(43). As a result, there has been intense interest in the development of more sophisticated three-dimensional assays. Cancer cells grown in three-dimensional spheroids are now widely used to investigate the effects of small molecules on tumor growth and other 
endpoints such as invasion and remodeling of the tumor matrix. More sophisticated assays, such as spheroid and organoids, have been developed to better represent the tumor and its microenvironment.

Here we follow a rational approach to create chemical libraries that are used for phenotypic screening to generate small molecules with selective polypharmacology that inhibit GBM growth without affecting non-transformed normal cell lines. Our approach combines catalogs of differentially expressed molecular targets identified by tumor genomic profiles along with cellular protein-protein interaction data to select a collection of targets with druggable binding pockets. Approximately 9000 in-house compounds are docked to each of these targets. Small molecules that are predicted to simultaneously bind to multiple proteins are selected for phenotypic screening using three-dimensional spheroids of patient-derived GBM cells. Compounds were tested in non-transformed primary normal cell lines in (i) a three-dimensional assay using CD34 ${ }^{+}$ progenitor cells and (ii) a two-dimensional assay using astrocytes. The effect of the compound on angiogenesis was also tested using a tube formation assay with brain endothelial cells. To uncover potential mechanisms of action, the compound was selected for RNA sequencing of compound-treated and untreated cells. Thermal proteome profiling was performed to identify potential targets. Cellular thermal shift assays using antibodies were used to confirm the binding of the compound to targets that emerged from the thermal proteome profiling study.

\section{RESULTS}

Target Selection, Virtual Screening, and Rank-Ordering of Chemical Library. A weakness of current implementations of phenotypic screening is the lack of rational approaches in the creation of chemical libraries. Here, we propose a strategy that uses the tumor's genomic profile to enrich chemical libraries for phenotypic screening (Fig. 1a). The process begins with the identification of druggable pockets on a large number of protein structures obtained from the Protein Data Bank (PDB)(44). In previous work, we searched for druggable binding sites on proteins implicated in a range of cancers and classified them in the context of functional importance(45). Druggable binding sites were classified based on whether they occurred at a catalytic site (ENZ), a protein-protein interaction interface (PPI), or an allosteric site (OTH).

Using our approach, druggable binding sites were identified for GBM. Gene expression profiles were collected for GBM patients from TCGA. A total of 169 GBM tumors and 5 normal samples have been characterized using RNA sequencing platforms. The data were used to perform differential expression analysis to identify genes that are overexpressed in GBM $(p<$ 
0.001, FDR < 0.01, and $\log _{2}$ fold change $\left.\left(\log _{2} F C\right)>1\right)$ (Fig. 1b). In addition, a set of somatic mutations was retrieved from GBM patients at TCGA and identified for 158 of the 169 tumor samples. In total, 755 genes with somatic mutations were overexpressed in GBM patient samples.

The set of 755 genes were subsequently filtered based on whether their protein products are involved in protein-protein interactions. Two large-scale protein-protein interaction networks of the human proteome were recently described by Rolland and co-workers(46). The first network is from literature curation of seven widely-used protein-protein interaction databases. The second network is based on systematically mapping human binary protein-protein interactions. The two protein-protein interaction datasets from both the literature-curated and experimentallydetermined networks were combined to form a large-scale protein-protein interaction network consisting of approximately 8000 proteins and 27000 interactions. The protein products of the genes implicated in GBM were mapped onto this protein-protein interaction network to construct a GBM subnetwork (Fig. 1c). Among the 755 previously-identified genes implicated in GBM, 390 had at least one interaction in the network. In total, 117 of the 390 proteins had at least one druggable binding site (Fig. 1d and Table S1).

To identify small molecules that inhibit phenotypes associated with GBM, an in-house library of approximately 9000 compounds was docked to the set of 316 druggable binding sites on proteins in the GBM subnetwork. The Support Vector Machine-Knowledge Based (SVR$\mathrm{KB})(47)$ scoring method was used to predict the binding affinities of each pair of proteincompound interactions. The number of druggable binding sites with affinities better than a given SVR-KB cutoff was used to rank-order compounds (Fig. 1e). In this work, an SVR-KB cutoff corresponding to a computational binding affinity of $10 \mathrm{nM}$ was used. Approximately 55 percent of compounds were predicted to bind to five or less binding sites, and 20 percent of the docked compounds were predicted to bind to none of the pockets in the GBM subnetwork (Fig. 1f). Less than 4 percent of the compounds were predicted to bind to at least 30 of the 316 binding sites. Small molecules with the highest number of predicted GBM targets were selected for further testing. A total of 154 compounds were selected for the first screen that were predicted to target between 38 and 86 binding sites on GBM-specific proteins. The mean number of predicted targets is 47 for the 154 compounds. The top 154 compounds were clustered with hierarchical clustering using chemical similarity. For each cluster, the compound corresponding to the cluster center was selected for phenotypic testing (Table S2).

Exploring Compounds in Patient-Derived GBM Spheroids. A total of 47 compounds selected from the library of 9000 compounds were tested in a three-dimensional spheroid viability 

Most compounds showed little to no effect on GBM43 cell viability, except for 1 (IPR-2025), which inhibited cell viability by $90 \%$ (Fig. 2 b). The compound was resynthesized and its stability was tested following incubation in buffer (Fig. 2c). The compound was stable in buffer. A follow-up concentration-dependent study of 1 revealed an $\mathrm{IC}_{50}$ of $3.7 \pm 0.1 \mu \mathrm{M}$ in GBM43 (Fig. $\mathbf{2 d}$ and $\mathbf{e}$ ). Compound 1 was tested in two additional glioblastoma spheroid models derived from different patients with recurrent GBM, namely GBM10 and SJ-GBM2. GBM10(50) is derived from an adult patient, while SJ-GBM2(51) is derived from a pediatric patient. The $\mathrm{IC}_{50}$ of 1 was $3.1 \pm 1.5 \mu \mathrm{M}$ and $2.9 \pm 1.9 \mu \mathrm{M}$ in GBM10 and SJ-GBM2, respectively. The effect of 1 on normal and nontransformed cell viability was explored using CD34+ progenitor cells and astrocytes (Fig. 2d). Cell viability studies for $\mathrm{CD} 34^{+}$cells were performed using a colony formation assay, while a monolayer MTT assay was used for astrocytes. Compound $\mathbf{1}$ had no effect on the cell viability of $\mathrm{CD} 4^{+}$or astrocyte cells up to $100 \mu \mathrm{M}$. For the sake of comparison, the standard-of-care temozolomide inhibits GBM43 with an $\mathrm{IC}_{50}$ of $244 \pm 24 \mu \mathrm{M}(52)$. However, GBM43 is known to be moderately resistant to temozolomide(53). An alternative treatment option is the chemotherapeutic CCNU (lomustine), which inhibited GBM43 and GBM10 cell viability weakly, showing about $50 \%$ inhibition at $100 \mu \mathrm{M}$ (Fig. 2f). It is important to note that the astrocyte assay is a 2-D assay, which is different than the 3-D assay used for the GBM cell viability studies, thus direct comparison of the exposure times between the two assays is not possible. Cells grown in 2-D are generally more sensitive to chemicals compared with cells grown in 3-D. In 2-D, cells are not in contact with each other, but they make contacts with the plastic surface, and adopt a flattened morphology. Cells in a 3-D environment, on the other hand, mimic the morphology of cells found in tumors due to the fact that cells form contacts with other cells, triggering distinct signaling pathways that makes them less sensitive to anti-tumor agents. In addition, cells at the center of spheroids experience hypoxia, which further enhances their survival, making them less prone to cell killing by compounds. Furthermore, in the 3-D environment found in spheroids, compounds must be able to diffuse to access cells that are at the center of these spheroids, which is often another mechanism of resistance, especially for compounds that are less likely to diffuse into these spheroids due to their physico-chemical properties.

The activity of 1 was also assessed in three pancreatic ductal adenocarcinoma patientderived spheroid models(54-56): Pa02C, Panc10.05 (Pa16C), and Panc198 (Pa20C). Pa02C is from liver metastasis of pancreatic cancer, while Panc10.05 and Panc198 are from the primary pancreatic tumor. Compound 1 showed no activity in Pa02C and Panc198 and weak activity in Panc10.05 with an $\mathrm{IC}_{50}$ of $26.0 \pm 5.9 \mu \mathrm{M} \mathrm{IC}{ }_{50}$. 
Structure-Activity Relationship (SAR) of 1 (IPR-2025). A set of 5 analogs from our internal library were identified from commercial libraries with high Tanimoto similarity to 1 (Table S3): 2 (GFI-027), 3 (IPR-1909), 4 (RAG-021), 19 (IPR-2024), and 20 (KLM-017). These 5 compounds were tested in a concentration-dependent manner in GBM43 (Fig. S1). Only 19 inhibited in a concentration-dependent manner like 1, although the compound only reaches $60 \%$ inhibition at $100 \mu \mathrm{M}$ in GBM10 and has an approximate $\mathrm{IC}_{50}$ of $33 \mu \mathrm{M}$ and no effect in GBM43. An analog-by-catalog approach was followed to identify another 15 derivatives. These compounds were tested in GBM43 and GBM10 in a concentration-dependent manner (Fig. S1). Substitution of the fused tricyclic moiety in 14 (IPR-3440), 20 (KLM-17), and 21 (IPR-3442), among others, led to loss of activity. Among the derivatives that share the fused tricyclic moiety of the parent, two also feature the sulfonyl group on $\mathrm{R}^{1} .5$ (IPR-3474) substitutes the toluene group on $\mathrm{R}^{1}$ with a biphenyl and lacks the carbonyl group on the pyrrolidinone group, while $\mathbf{6}$ (IPR3476) replaces the pyrrolidinone group with an amine linker. These two compounds suggest the importance of the carbonyl group on the pyrrolidinone in $\mathrm{R}^{1}$. Similarly, compounds that lack the sulfonyl group on $\mathrm{R}^{1}$, like $\mathbf{3}$, also lacked activity.

To further assess the importance of the sulfonyl moiety, three additional compounds, 22 (IPR-3502), 23 (IPR-3503), and 24 (IPR-3504), were synthesized that lack key moieties in R ${ }^{1}$ (Fig. 3). The removal of the carbonyl group on the pyrrolidinone, sulfonyl linker, or both the sulfonyl linker and the methylbenzene group in $\mathbf{2 2 , 2 3}$, and $\mathbf{2 4}$, respectively, led to loss of activity in both GBM43 and GBM10. Three additional derivatives were synthesized to add halogen groups to 1. Substitution of the methyl group in $\mathrm{R}^{3}$ with a trifluoromethyl in 25 (IPR-3593) resulted in nearly ten-fold decrease in $\mathrm{IC}_{50}$ across each of the GBM spheroids compared to 1 . Chlorine atoms were added to two separate positions of the fused ring structure in 26 (IPR-3594) and 27 (IPR3595), resulting in no activity in either compound across the GBM spheroids. Among the 21 analogs of 1 that were tested across each of the three GBM spheroids, only the trifluoromethyl 25 resulted in measurable $\mathrm{IC}_{50} \mathrm{~s}$.

Compound 1 Inhibits Tube-Formation in Matrigel. Since the seminal work of Folkman(57), uncontrolled angiogenesis (the process of new blood vessel growth from existing ones) has become an established hallmark of cancer(1). Solid tumors require a dedicated blood supply once they reach a certain, limiting size, and antiangiogenic agents can block tumor growth by starving the tumor of oxygen and nutrients. A so-called "angiogenic switch" is an integral part of tumor development: varied tumor types secrete vascular endothelial growth factor (VEGF) and other proangiogenic stimuli and downregulate antiangiogenic proteins. There have also been 
some promising clinical results with angiogenesis inhibitors in improving progression-free survival in both primary and recurrent $\operatorname{GBM}(58,59)$. This cancer is also characterized by microvascular proliferation(60) and high levels of VEGF(61). Given the ample evidence of the importance for angiogenesis in the biology of these tumors, there is significant need to identify novel compounds with specific antiangiogenic activity. The parent compound 1 was tested for its ability to inhibit tube formation of brain microvascular endothelial cells (Fig. 2g). Compound 1 inhibited tube formation with approximate $0.1 \mu \mathrm{M} \mathrm{IC}_{50}$ (Fig. 2h). The effect of compound 1 on BMECs revealed an $I_{50} 3.5 \mu \mathrm{M}$ after a 48-hour exposure (Fig. S2). In comparison, pronounced effects on tube formation were seen at doses well below this, i.e. $100 \mathrm{nM}$ and $1 \mu \mathrm{M}$ (Fig. 2h). Moreover, the tube formation assay was conducted over a short term (8 hours), and as seen in the images in Fig. $\mathbf{2 g}$, there were no obvious signs of cell death at these concentrations.

\section{Structural Analysis and RNA Sequencing to Uncover Compound 1 Mechanism of}

Action. The binding modes of 1 to each of the targets predicted by the SVR-KB scoring function were examined in detail. Each target was classified using the structural context of the binding site and functional context of the protein (Table 1). Generally, the binding modes of 1 were at allosteric sites outside the active site on enzymes. Three allosteric sites were adjacent to known proteinprotein interaction interfaces on NCF2, NEDD4, and PYGL. Similarly, 1 was predicted to bind to allosteric sites adjacent to the active sites on KIF11 and TAP1. The compound was predicted to bind at pockets at the protein-protein interfaces at the PLK1 polo box and at the homodimers of NCF1 and PNP. The compound was also predicted to bind to the $\beta$-propeller structures of CDC20, GNB1, ITGA5, and RACK1.

RNA sequencing was performed on untreated GBM43 cells and GBM43 cells treated with $10 \mu \mathrm{M} 1$ to validate the predicted targets of 1 and uncover a potential mechanism of action (Fig. 4a). Differential expression analysis $\left(p<0.001\right.$, FDR $\left.<0.01,\left|\log _{2} F C\right|>1\right)$ revealed a set of 15 overexpressed and 20 underexpressed genes in GBM43 cells treated with 1 (Fig. 4b). The sets of overexpressed and underexpressed were separately analyzed for overrepresented GO terms. No significantly overrepresented terms were found among either set of differentially expressed genes. The set of differentially expressed genes (DEGs) were compared with those known to be causally implicated in cancer using the Cancer Gene Census (CGC)(62). Two DEGs were previously identified as oncogenes. The transcription factor GATA2 has been shown to promote GBM progression through the EGFR/ERK/Elk-1 pathway(63). Similarly, the kinase KDR (VEGFR2) is a known oncogene in lung, blood, and skin cancers and plays a key role in regulating angiogenesis(64). 
The expression profile of cells treated with 1 was compared to the gene signatures of previously characterized compounds and gene knockdowns using the LINCS L1000 platform. The L1000 platform is an extension of the Connectivity Map (CMap) project(65), which used similarities in gene expression signatures to discover shared mechanisms of action between small molecule and genetic perturbations. The L1000 platform expands on CMap and uses a panel of approximately 1,000 landmark genes to characterize the molecular profiles of over 19,000 compound and 5,000 gene perturbations across nine cell lines(66). To compare the gene expression profile of 1 to the existing signatures in L1000, a signature query was generated using the sets of overexpressed and underexpressed genes. The similarity between the signature query is compared with all other signatures in L1000 using a connectivity score $(\mathrm{T})$, which corresponds to the percentage of all reference gene sets that are more similar than the observed gene signature. The most similar 30 gene and small molecule perturbations of 1 are shown in Fig. 4c. The most similar gene signatures are gene knockdowns of GNA15 and OGFOD1. The G protein $\alpha$-subunit GNA15 is part of the heterotrimeric G protein complex consisting of $\alpha$-subunit and $\beta \gamma$ complex, which mediate downstream signaling of G protein-coupled receptors (GPCRs)(67). While no a-subunits were among the targets predicted to bind to the compound, both the $G$ protein $\beta$-subunit GNB1 and $\beta$-like subunit RACK1 were predicted targets of 1 . RACK1 acts as a scaffolding protein in transcription regulation of the transcription factor EIF4E(68). Gene silencing and knockdown studies of RACK1 have resulted in promotion of apoptosis and inhibition of cell proliferation, migration, and invasion in glioma(69,70). The oxygenase OGFOD1 belongs to a family of transcriptional factor and chromatin regulators and has been found to inhibit cell proliferation in breast cancer cells(71). Also among the knockdown gene signatures most similar to the gene signature of 1 in L1000 are the tumor suppressors AES(72) and TP53BP2(73).

Thermal Proteome Profiling to Identify Potential Targets of 1 (IPR-2025). Once a compound is identified in a phenotypic screen, the challenge is to identify its targets. Several methods have been used in the past for target identification, such as biochemical, genomic, or computational approaches(74-77). Computational methods make use of statistical and machine learning methods to link a novel compound to existing compounds by identifying common features between the two. Previously developed algorithms have used similarities in compound scaffolds(78,79), protein structure similarity(80), side effects(81), and bioactivities(82) to infer a compound's target. A more recent mass spectrometry-based method is thermal proteome profiling, which allows for systematic identification of a compound's direct targets by analyzing shifts in melting temperature of the targets in cells $(83,84)$. As a compound binds to its protein 
target, the protein becomes more resistant to heat-induced unfolding and denaturation. This in turn increases the melting temperature of the protein.

Thermal proteome profiling was used to identify potential targets of 1 . GBM43 cells were treated with $10 \mu \mathrm{M}$ of 1 at six temperatures between 37 and $60^{\circ} \mathrm{C}$. Following heating, soluble proteins were extracted in phosphate-buffered saline (PBS) buffer, quantified and digested into peptides using trypsin. Digested peptides were analyzed by LC-MS/MS and quantified using label-free precursor-ion (MS1) intensity. The iBAQ values (intensities normalized by the size of the proteins) acquired after data analysis using MaxQuant(85) were used to fit thermal melting curves and to determine the shift in melting temperature between untreated and compoundtreated proteins $\left(\Delta \mathrm{T}_{\mathrm{m}}\right)$. We acquired quantitative iBAQ data for over 1700 proteins across all temperatures at $1 \%$ FDR, of which the melting curves of 129 proteins were determined from the thermal profiling (Fig. 5a). A cutoff of $3{ }^{\circ} \mathrm{C}$ was used to identify proteins with significant thermal shifts when treated with 1. A total of 12 proteins were identified with $\Delta T_{m} \geq 3{ }^{\circ} \mathrm{C}$ (Fig. $\mathbf{5 b}$ and S3). Interestingly, RACK1 was both predicted to be a target of 1 (Table 1) as well as showed a significant thermal shift in TPP. In contrast, a set of 7 proteins were identified to be destabilized when exposed to 1 , resulting in a change in melting temperature $\Delta \mathrm{T}_{\mathrm{m}} \leq-3^{\circ} \mathrm{C}$ (Fig. $\mathbf{5 C}$ and S4). The largest observed destabilization was in DSTN, a component of the cytoskeleton.

Integrated Analysis of Computational, RNA-seq, and TPP Data for Potential Mechanisms of Action. To uncover the potential mechanism of action of 1, proteins predicted to bind 1 by SVR-KB, and proteins implicated by compound-specific changes by RNA-seq profiling, L1000 comparisons, and thermal proteome profiling were integrated into a protein network (Fig. 5d). Proteins implicated from each of the four sources were connected based on structural and non-structural evidence using the STRING database(86). STRING incorporates protein-protein interactions from both direct physical interactions as well as indirect functional associations. Interactions come from a variety of sources, including experimental interactions from proteinprotein databases, pathway knowledge from manually curated databases, co-expression studies, and homology. Multiple interconnected modules are formed in the protein subnetwork. The largest module features proteins associated with the cell cycle (PPP1CB, PLK1, EXO1, and CDC20) and metabolism of compounds with nucleobases (KIF11, EXO1, TOP2A, and CENPE). Within this cluster, several targets were predicted to bind to 1, including EXO1, TOP2A, CENPE, and KIF11. Three proteins in this cluster showed positive thermal shifts, DCTN1, KIF5B, and PPP1CB, as well as a negative thermal shift in ARCN1. Both DCTN1 and KIF5B act as motor proteins: DCTN1 is a subunit of dynactin, which binds to dynein and acts as cytoskeletal motors in cellular 
transport(87), while KIF5B is a motor protein involved in mitosis and meiosis, and acts as a catalytic subunit of the tumor suppressors NF1 and NF2(88). Interestingly, upregulation of the dynactin mediator DYNC1I1 is observed in the RNA-seq analysis. A second interconnected module is formed by the $G$ protein $\beta$-subunit and $\beta$-subunit-like proteins GNB1 and RACK1, respectively. The prediction of RACK1 as a direct target of 1 is supported by direct evidence from the thermal proteome profiling, as well as a similar stability shift in the RNA-binding protein HDLBP. Similarly, upregulation of the GPCR PTH2R and downregulation of the potassium channel KCNJ10, which belong to similar regulation pathways as GNB1, was also observed in the analysis of RNA-seq derived from treated versus non-treated GBM spheroids.

To confirm direct binding to RACK1, the effects of 1 and the inactive analog 22 were examined in a concentration-dependent manner with an antibody-based cellular thermal shift assay (CETSA) (Fig. 5e; top panel). Similar to thermal proteome profiling, GBM43 cells are treated with varying concentrations of the compound and then heated to $45^{\circ} \mathrm{C}$. Direct binding of the compound to the protein will result in protein stabilization and an increase in melting temperature. In GBM43, there is an increase in RACK1 abundance at 50 and $100 \mu \mathrm{M}$ in cells treated with 1 , suggesting that RACK1 may be among the targets of 1 . To rule out non-specific binding of the compound, the assay was also performed on GAPDH, an enzyme involved in glycolysis, resulting in no difference in protein abundance with increase concentration of compound. When GBM43 were treated with the inactive analog $\mathbf{2 2}$, the concentration of the compound did not affect protein abundance compared to the DMSO control (Fig. 5e; bottom panel).

\section{DISCUSSION}

Tumors such as GBM exhibit multiple phenotypes that include uncontrolled growth, angiogenesis, invasion, and immune evasion. These phenotypes are driven by perturbations in genes and their protein products working in concert across multiple signaling pathways. The multiple targets involved in promoting tumor growth and metastasis pose a major challenge for the development of small-molecule therapeutic agents to treat these tumors. To date, the most common strategy in cancer drug discovery is to develop small molecules that modulate the function of a single target. This approach has not yielded therapeutic agents that are efficacious for complex tumors such as GBM. At the other extreme, phenotypic screening has been used to uncover novel anti-cancer agents(17). This strategy has led to several approved drugs, including eribulin in breast cancer, nelarabine in T-cell lympoblastic leukemia and lymphoma, and trametinib in metastatic melanoma(89). However, the limited diversity of chemical libraries, the 
use of immortalized cell lines, and the reliance on two-dimensional cellular assays has mostly led to cytotoxic cell cycle inhibitors that have not yielded efficacy in patients(90).

A data-driven approach that combines genomic, structural, and protein-protein interaction data to enrich chemical libraries using computational docking has the potential to overcome the limitations of phenotypic screening for cancer drug discovery. Here, in a first proof-of-concept study, we propose a screening strategy that takes integrates vast orthogonal datasets including (i) tumor genomic data from patient-derived GBM samples available at TCGA, (ii) threedimensional structures of human proteins that enable the identification of druggable pockets in proteins implicated in GBM, and (iii) the large number of cellular protein-protein interactions that have been mapped over the past decade using yeast-two-hybrid and other methods. Specifically, our approach initially utilizes expression data from TCGA to select all genes that are overexpressed and mutated in GBM. The PDB is subsequently mined to retrieve available protein structures that are encoded by these genes. Druggable pockets within these structures are identified and used for structure-based screening to identify potential small-molecule inhibitors. Proteins that are known to be involved in protein-protein interactions and possess druggable pockets are used for structure-based docking of an in-house library of 9,000 compounds. The resulting protein-compound complexes were ranked to select 50 small molecules that bind to the highest number of GBM-specific proteins. The resulting compounds were tested in a cell viability assay utilizing patient-derived GBM cells grown in a physiologically relevant three-dimensional format. Our strategy has a significant advantage over standard phenotypic screening, namely that large libraries containing thousands of compounds can be enriched to select a small collection of candidates that can be tested in more sophisticated assays and multiple phenotypes. Two assays are used, spheroid growth and tube formation assay in Matrigel. We also strictly use patientderived low-passage cell lines to overcome the limitations of existing phenotypic screens that are done on established cell lines. In addition to using GBM cancer cell lines, we also employ low passage pancreatic ductal adenocarcinoma cell lines as well as normal non-transformed cells such as $\mathrm{CD} 34^{+}$progenitor cells and astrocytes.

Compound collections were initially screened at a single concentration in duplicate using GBM43 cells grown in 3D spheroids. In the set of compounds that were predicted to maximally bind to GBM-specific targets, one compound, namely 1 (IPR-2025), showed substantial inhibition of cell viability. A concentration-dependence study revealed that 1 (IPR-2025) showed high potency in all three patient-derived GBM cell lines with $I_{50} \mathrm{~S}<4 \mu \mathrm{M}$. The compound was tested for its effect on tube formation in Matrigel, an indication of their potential usefulness in blocking 
angiogenesis and a key feature of GBM tumors, inhibiting with sub-micromolar $I_{50}$. The compound was tested in both normal non-transformed human CD34+ progenitor cells and primary brain astrocytes. Significantly, 1 had no effect on colony formation of CD34+ cells or astrocyte cell viability suggesting that there is a therapeutic window. To put the activity in perspective, standardof-care temozolomide inhibits GBM43 growth with an approximate $\mathrm{IC}_{50}$ of $250 \mu \mathrm{M}$, consistent with the high therapeutic doses used in GBM.

RNA-seq was initially employed to uncover a potential mechanism of action for $\mathbf{1}$ in GBM43. Compound 1 exhibited high selectivity as relatively few genes were affected by this compound. The L1000 platform was employed to identify gene knockdowns that led to a similar effect on gene expression. However, L1000 utilizes adherent cell cultures and established cell lines in cancers other than GBM. In contrast, GBM43 is a low-passage patient-derived cell line grown as a spheroid model and is expected to have a different underlying gene expression profile. Interestingly, the expression profile of 1 was most similar to the knockdown of G protein GNA15, which belongs to the same family as the predicted target GNB1 and structural homolog RACK1.

Considering the GBM-specific activity of 1 (IPR-2025) and its lack of cytotoxicity in normal non-transformed cell lines, thermal proteome profiling was used to identify potential targets of this compound. TPP uncovered up to 11 potential targets of $\mathbf{1}$, including RACK1 and KIF5B. It is interesting that among them, one target (RACK1) was also among the targets of 1 that emerged from the structure-based docking and ranking analysis. Analysis of the predicted binding mode reveals that the compound may bind within the central tunnel of the $\beta$-propeller structure. Followup CETSA analysis seems to support the fact that 1 may bind to RACK1 directly in cell culture. It is important to note that the TPP list is likely not a comprehensive list of all direct targets of 1 , and it is also likely that the 20 top targets identified in TPP may not be all targets of 1 . Furthermore, RACK 1 is a scaffold protein that is engaged in multiple protein-protein interactions by creating a large multi-protein complex. Even if we were able to confirm RACK1 direct binding, it would not establish that the compound inhibits RACK1 protein-protein interactions. Also, it is worth noting that the compound was designed to selectively bind to multiple targets. It is possible that the biological response that is observed as a result of treatment with compound is the result of binding of the compound to other targets. Further mechanistic studies beyond the scope of this manuscript will have to be performed to establish the exact mechanism of this compound.

Several derivatives of compound 1 either from commercial sources or from our own synthesis were tested for inhibition of cancer cell viability. Ultimately, identification of all targets will be required to better explain the observed SAR. However, structure-activity analyses can be 
performed using the chemical structure of compounds and their biological activity. Compounds 2-21 were obtained from commercial sources through a substructure search. They may share structure with 1, but they have key differences that makes them in active. For example, compounds 7-18 and 20-21 lack the dibenzofuran group of 1 . This group appears to be critical for biological activity. In fact, slight modifications at this moiety, such as introduction of chlorine atoms in compounds 26 and 27 led to complete loss of activity. While compounds 2-6 and compound 19 have the dibenzofuran moiety, they are substantially different in structure and lack the critical $\mathrm{N}$-acylsulfonamide core. Compounds 22-24 were designed to explore the importance of the $\mathrm{N}$-acylsulfonamide on compound 1. N-acylsulfonamides are known to react with nucleophiles such as serine residues. The $\mathrm{N}$-acylsulfonamide moiety of compound $\mathbf{1}$ could possibly react with serine, threonine, or tyrosine nucleophiles as illustrated in Fig. S5. Replacing the $\mathrm{N}$-acylsulfonamide carbonyl with methylene to generate 22 resulted in complete elimination of compound activity. A similar observation was made when the sulfone was replaced with methylene in compound 23. We wondered if the product compound (Fig. S5) following nucleophilic attack of the $\mathrm{N}$-acylsulfonamide is behind the biological activity of compound 1 . Compound 24 showed no activity, suggesting that a combination of binding and covalent modification is likely behind the activity of compound 1 . However, the fact that subtle modifications to other parts of the compound, such as introduction of chlorine atoms in $\mathbf{2 6}$ and 27, led to substantial loss in activity, suggests that the biological activity of compound 1 is a combination of binding and covalent modification.

In summary, we implement a multi-target screening approach that integrates cancer genomics with the druggable protein interactome to identify therapeutic candidates of GBM. The strategy of selecting compounds that were predicted to either target the highest number of GBMspecific proteins yielded a candidate compound. We pursued the compound in RNA-seq to discover potential mechanisms of action. Thermal proteome profiling of 1 revealed possible targets, including the computational predicted target RACK1. The ability of 1 to selectively target GBM phenotypes without affecting normal cell viability makes it suitable as a lead compound to uncover new targets in GBM and to develop potential therapeutic agents with multi-targeting properties.

\section{MATERIALS AND METHODS}

Cell Culture. The SJ-GBM2 cell line was obtained from the Children's Oncology Group. The GBM10 and GBM43 xenografts were a kind gift from Dr. Jann Sarkaria (Mayo Clinic), and tumors were expanded by passage in the flank of NOD/SCID $\gamma^{\text {null }}$ mice. To generate GBM10 and 
GBM43 cell lines, tumors were harvested, disaggregated, and maintained in 2.5\% FBS for 14 days on Matrigel-coated plates (BD Biosciences) to remove murine fibroblasts as previously described (50). Cell lines were propagated in DMEM with 10\% FBS medium with glutamine (Cellgro, Manassas, VA) for no more than 7 passages in $5 \% \mathrm{CO}_{2}$ at $37^{\circ} \mathrm{C}$. Cell line identity was confirmed by DNA fingerprint analysis (IDEXX BioResearch) for species and baseline shorttandem repeat analysis testing. The pancreatic cancer cells used in these studies were lowpassage patient-derived PDAC cell lines (fewer than 35 passages from patient tumors) and that were received from Dr. Anirban Maitra (The Johns Hopkins University) and maintained as previously described $(55,91)$. Pa02C, Panc10.05, and Panc198 were cultured in DMEM medium and supplemented with $10 \% \mathrm{FBS}$ in $5 \% \mathrm{CO}_{2}$ at $37^{\circ} \mathrm{C}$ for fewer than 10 passages. Cell line identity was confirmed by DNA fingerprint analysis (IDEXX BioResearch) for species and baseline shorttandem repeat analysis testing and cells were routinely checked for mycoplasma.

GBM and PDAC 3D models. GBM10, GBM43, and SJ-GBM2 spheroids were generated by plating early-passage cells at $2.5 \times 10^{4}$ cells per well in 96-well ultralow attachment plates (Corning Inc.) in DMEM/F12 (1:1; GIBCO) supplemented with 2\% B27 supplement (GIBCO), 20 $\mathrm{ng} / \mathrm{mL}$ epidermal growth factor (EGF), and $20 \mathrm{ng} / \mathrm{mL}$ fibroblast growth factor (FGF) (Peprotech) for 2 days. The spheroids were then treated with compounds and growth analyzed by Alamar blue staining at day 5 following compound exposure as previously described by our group (52). Astrocyte cell proliferation was determined by The CellTiter 96® AQueous Non-Radioactive Cell Proliferation Assay (MTS) (Promega) performed in 96-well plates. Primary human fetal astrocytes were purchased from ABM (cat \#T4033) and cultured in progenitor astrocyte growth media defined by Barris and co-workers (92). Cells were seeded at $8 \times 10^{3} /$ well in DMEM medium with 10\% FBS and 1\% 100X Penicillin/Streptomycin. Cell numbers were determined after 3 days of incubation with DMSO or compounds at indicated concentrations. $20 \mu \mathrm{L}$ of MTS solution was added to the well. After 1 hour incubation at $37^{\circ} \mathrm{C}$, the absorbance was measured at $490 \mathrm{~nm}$. Experiments were done in triplicate.

PDAC cells were grown as tumor spheroids as described previously using pancreatic cancer cells stably transduced with TdTomato (red) and the intensity of the spheroids over time was quantitated as described in our previous studies $(56,91,94)$. Briefly, PDAC cells $(1,000$ cell/well) were seeded in ultralow adherence 96-well plates (Corning Inc.) in media containing 3\% reduced growth factor Matrigel (Corning Inc.) and 5\% FBS. Spheroids were fed or treated on days 4 and 8 . Red fluorescence intensity was measured at day 12 following plating using the Thermo 
ArrayScan (Thermo Fisher Scientific). Percent viability for drug-treated wells was quantitated compared to media control.

Half maximal inhibitory concentration $\left(\mathrm{IC}_{50}\right)$ of cell viability curves were determined using a four-parameter logistic model (93). $I C_{50}$ values represent relative $I C_{50} S$, that is, the minimum parameter of the model is the lowest cell viability observed. Cell viability curves were determined using the non-linear least-squares method as implemented in the SciPy package in Python.

Colony-forming Unit (CFU) Assay. Briefly, purified human umbilical cord blood CD34+ cells were obtained from the Angio BioCore (IUSCC) and the $I_{50}$ values determined by dose response curves. CD34+ cells were incubated with compounds and plated in the presence of the compounds at $2 \times 10^{3}$ cells per $35 \mathrm{~mm}$ dish in MethoCult H4434 (Stemcell Technologies) as previously described (95). The number of clonogenic progenitor colonies was enumerated under a light microscope at day 14 post-compound exposure.

TCGA GBM Gene Expression and Somatic Mutations. RNA-sequencing and mutation data from GBM were identified from The Cancer Genome Atlas (TCGA) project $(12,96)$ and collected from the National Cancer Institute's Genomic Data Commons (GDC) data portal(97). As part of the GDC pipeline, 169 tumors and 5 normal samples were previously aligned against the GRCh38 genome assembly using STAR 2-pass (98) and quantified using HTSeq (99). Level 3 HTSeq fragment counts were collected from all 174 samples and used these as read counts for differential expression analysis. Differentially expressed genes were identified using the edgeR(100) package and the quasi-likelihood F-test pipeline (101) for hypothesis testing. A counts-per-million (CPM) threshold corresponding to a library count of 10 (CPM $\approx 0.15)$ was used to filter out genes with low reads. Overexpressed genes were defined as those with $p<0.001$, FDR $<0.01$, and $\log _{2}$ fold change $\left(\log _{2} F C\right)>1$. Ensembl Gene identifiers from the differential expression analysis were mapped to UniProt(102) identifiers using BioMart(103). Open-access mutation annotation format (MAF) files for GBM were also collected from the GDC data portal. The GDC pipeline used the MuTect2(104) pipeline for mutation calling. As part of the GDC's workflow, low quality and potentially germline variants were removed. Somatic mutations were mapped to their corresponding proteins using the UniProt ID.

Protein-Protein Interaction Network. Rolland and associates (46) recently constructed two large-scale protein-protein interaction networks. The first is based on literature curation and benchmarking of seven protein-protein interaction databases, producing a network of approximately 5500 proteins and 12000 interactions. The second is based on systematic 
experimental testing of pairwise combinations of approximately 13000 genes and describes a network of approximately 4200 proteins and 14000 interactions. Entrez genes were mapped to UniProt identifiers using UniProt's mapping tool (http://www.uniprot.org/mapping/) and these two networks were combined together using the NetworkX (105) module in Python. The resulting protein-protein interaction network consists of approximately 27000 interactions across 8000 proteins and was visualized using Cytoscape (106) (v3.3.0).

Druggable Binding Sites. In a previous work, a set of druggable binding pockets were identified in the human proteome and explored in the context of functional importance, signaling pathways, and the human interactome(45). In brief, a set of 4124 proteins were identified in the human proteome that have been solved with crystallography. Druggable binding pockets were found on these proteins using the SiteMap $(107,108)$ module in Schrödinger (Schrödinger LLC, New York, NY). Up to 10 binding sites were mapped for each structure. Each binding site was evaluated by its ability to bind a ligand (SiteScore) and its druggability (DrugScore). Only binding sites with SiteScore and DrugScore above 0.8 were kept. In total, 5498 binding sites on 2607 proteins were found. Each binding site identified by SiteMap was visually inspected and manually annotated to determine its functional role in the protein. If an active site residue was in contact with the SiteMap spheres, or if a catalytic molecule or inhibitor occupied the space of the spheres, the binding site was labeled 'enzyme' (ENZ). If the binding site was at a protein-protein interaction (PPI) interface on the original structure or on any of the aligned structures, the binding site was labeled 'PPI'. Otherwise, if the binding site was neither enzyme nor part of the interaction interface, it was labeled 'other' (OTH).

Virtual Screening GBM Network. The set of druggable binding sites on proteins which were (i) overexpressed in GBM, (ii) featured somatic mutations in GBM, and (iii) were part of the PPI interactome were selected. Specifically, we focused on binding sites that were classified as either PPI or OTH and omitted those with solely ENZ classifications. In total, 316 binding sites were identified. The set of binding pockets were docked against an internal chemical library of small molecules. These compounds are from previous screening campaigns primarily focused on targeting tight protein-protein interactions. Compounds possessing pan-assay interference compound (PAINS)(109) or rapid elimination of swill (REOS)(110) moieties were discarded. This resulted in a compound library of 9075 small molecules and their enantiomers. Compounds were docked against 316 binding sites on proteins implicated in GBM using AutoDock Vina(111) (v1.1.2). The average coordinates of the SiteMap spheres were used to identify the centroid of the binding site for docking. Each binding site was represented as a box with dimensions of $21 \AA$ 
$\times 21 \AA \times 21 \AA$. All other parameters were set to default values. Docked poses were rescored using the previously developed Support Vector Machine-Knowledge Based (SVR-KB)(47) scoring function. In this scoring function, knowledge-based pair-potentials of co-crystal complexes are used to train a regression model to predict the binding affinity of docked complexes. To rank-order compounds, the number of pockets with binding affinities better than a given SVR-KB cutoff for that compound were counted. Here, an SVR-KB cutoff corresponding to a predicted binding affinity of $10 \mathrm{nM}$ was used. Compounds were rank-ordered using the number of binding sites predicted to bind to the compound with an affinity better than the SVR-KB cutoff. The top 154 compounds were retrieved and clustered using the Canvas module in Schrödinger. A hashed binary fingerprint corresponding to atom triplets of Daylight invariant atom types were generated for the selected compounds. Compounds were hierarchically clustered using their atom triplet fingerprints and average linkage clustering to 50 clusters. The Tanimoto similarity between a pair of fingerprints was used as the distance metric. Compounds corresponding to the centroid of each cluster were selected for experimental validation.

Tube Formation Assay. The Matrigel based tube formation assay was performed as previously described (112). Briefly, $50 \mu \mathrm{L}$ Matrigel (Corning, Corning, NY) was allowed to solidify in a 96 well black, clear bottom plate at $37^{\circ} \mathrm{C}$ for $20 \mathrm{~min}$. Primary brain microvascular endothelial cells (BMECs; Cell Systems, Seattle, WA) were added to the solid Matrigel at 15,000 cells per well in $100 \mu \mathrm{L}$ endothelial growth medium-2 (EGM-2, Lonza, Walkersville, MD) and dosed with appropriate concentrations of compound with $1 \mu \mathrm{L}$ DMSO per well. Tube formation was observed every 2 hours by brightfield microscopy and images were taken after 8 hours of tube formation. Six images per treatment were analyzed with the Angiogenesis Analyzer plugin for ImageJ(113), and BMEC total tubule length for treated cells was normalized to DMSO-treated samples. Statistical analysis using one-way ANOVA with Dunnett's post hoc test to compare treatments with DMSO control was completed using GraphPad Prism (v7.0, GraphPad Software, La Jolla, $\mathrm{CA})$.

RNA-Seq of Compound-Treated Cells. GBM43 cells were treated with $10 \mu \mathrm{M} 1$ (IPR2025). RNA-seq analysis was conducted in triplicates for the untreated control and 1. After compound treatment, GBM43 cells were collected and rinsed with 1× PBS. The pellet was first homogenized in RLT lysis buffer plus $\beta$-mercaptoethanol and total RNA was extracted with RNeasy Mini Kit (Qiagen) in combination with QIAshredder (Qiagen). The RNA quality was assessed by A260/A280 ratio (NanoDrop) and stored at $-80^{\circ} \mathrm{C}$. 
Total RNA was evaluated for its quantity and quality using the Agilent Bioanalyzer 2100 system. For RNA quality, a RIN number of 7 or higher was desired. A total of 500 ng RNA was used. The cDNA library was prepared through mRNA purification and enrichment, RNA fragmentation, cDNA synthesis, ligation of index adaptors, and amplification, following the TruSeq Stranded mRNA Sample Preparation Guide, RS-122-9004DOC, Part\# 15031047 Rev. E (Illumina, Inc.). Each resulting indexed library was quantified, and its quality accessed by Qubit and Agilent Bioanalyzer, and multiple libraries pooled in equal molarity. Five $\mu \mathrm{L}$ of $2 \mathrm{nM}$ pooled libraries per lane was then denatured, neutralized, and applied to the cBot for flow cell deposition and cluster amplification, before loading to HiSeq 4000 for sequencing (Illumina, Inc.).

The RNA-seq aligner from STAR(98) (v2.5) was used to map RNA-seq reads to the human reference genome (hg38), with the following parameter: '--outSAMmapqUnique 60'. Uniquely mapped sequencing reads were assigned to genes using featureCounts(114) (from subread $v 1.5 .1$ ) with the following parameters: '-s $2-Q 10$ '. The genes were filtered for further analysis if their count per million (CPM) of reads was less than 0.5 in more than 4 samples. The method of trimmed mean of $M$ values (TMM) was adopted for gene expression normalization cross all samples, followed by differential expression (DE) analysis between different conditions using edgeR(100,115) (v3.20.8).

Differentially expressed genes (DEG) were determined using p-value and false discovery rate (FDR) cutoffs of 0.001 and 0.01 , respectively. A fold change $\left(\left|\log _{2} F C\right|\right)$ cutoff of 1 was used. The functional analysis was performed on overexpressed and underexpressed DEGs separately with a cutoff of FDR $<0.05$ to identify significantly overrepresented Gene Ontology (GO) and/or KEGG pathways using DAVID(116,117) and PANTHER(118).

Thermal Proteome Profiling. GBM43 cells were trypsinized, washed with PBS, and suspended in PBS supplemented with a protease inhibitor cocktail (Sigma-Aldrich). Suspended cells were treated with $10 \mu \mathrm{M} 1$ (IPR-2025) or DMSO for 1 hour at $37^{\circ} \mathrm{C}$, then the treated cells were separated into fractions, each with $5 \times 10^{6}$ cells for proteome thermal profiling. Fractions were heated for 3 min to the following temperatures: (i) $37^{\circ} \mathrm{C}$, (ii) $40^{\circ} \mathrm{C}$, (iii) $45^{\circ} \mathrm{C}$, (iv) $50^{\circ} \mathrm{C}$, (v) $55^{\circ} \mathrm{C}$, and (vi) $60^{\circ} \mathrm{C}$, then incubated for $3 \mathrm{~min}$ at room temperature and frozen in liquid nitrogen. Samples were lysed with three freeze-thaw cycles using liquid nitrogen and $25^{\circ} \mathrm{C}$ water bath. Cell lysates were centrifuged at $100,000 \times \mathrm{g}$ for $20 \mathrm{~min}$ at $4{ }^{\circ} \mathrm{C}$ to separate protein aggregates from soluble proteins. Supernatants were collected for LC-MS/MS. 
Protein concentration in each sample was determined by bicinchoninic acid (BCA) assay with BSA as a standard. About $50 \mu \mathrm{g}$ protein from each sample was denatured by adding $50 \mu \mathrm{L}$ of $8 \mathrm{M}$ urea, reduced by incubating with $10 \mathrm{mM}$ dithiothreitol (DTT) at $50{ }^{\circ} \mathrm{C}$ for $45 \mathrm{~min}$, and cysteine alkylated with $20 \mathrm{mM}$ iodoacetamide (IAA) in the dark for $45 \mathrm{~min}$ at room temperature, followed by incubation with $5 \mathrm{mM}$ DTT for $20 \mathrm{~min}$ at $37^{\circ} \mathrm{C}$ to scavenge residual IAA. Proteins were digested using sequencing grade trypsin and Lys-C mix from Promega at a 1:25 (w/w) enzyme-to-protein ratio at $37{ }^{\circ} \mathrm{C}$ overnight. The digested peptides were cleaned using $\mathrm{C} 18$ silica micro spin columns (The Nest Group Inc.) and peptides were eluted using $80 \%$ acetonitrile containing $0.1 \%$ formic acid (FA). The samples were vacuum dried and re-suspended in $3 \%$ acetonitrile and $0.1 \%$ formic acid. The peptide concentration was determined by BCA assay with BSA as a standard. Peptides concentration was adjusted to $0.2 \mu \mathrm{g} / \mu \mathrm{L}$, soluble and insoluble samples were mixed together and $5 \mu \mathrm{L}$ was used for LC-MS/MS analysis as described below.

Samples were analyzed by reverse-phase LC-ESI-MS/MS system using the Dionex UltiMate 3000 RSLCnano System coupled to the Q Exactive High Field (HF) Hybrid QuadrupoleOrbitrap MS and a Nano-electrospray Flex ion source (Thermo Fisher Scientific). Peptides were loaded onto a trap column ( $300 \mu \mathrm{m} \mathrm{ID} \times 5 \mathrm{~mm}$ ) packed with $5 \mu \mathrm{m} 100 \AA$ PepMap C18 medium, and then separated on a reverse phase column $(15 \mathrm{~cm}$ long $\times 75 \mu \mathrm{m}$ ID) packed with $3 \mu \mathrm{m} 100$ A PepMap C18 silica (Thermo Fisher Scientific). All the MS measurements were performed in the positive ion mode, using 120 min LC gradient as previously described(119). The mass spectrometer was operated using standard data-dependent mode. MS data were acquired with a Top20 data-dependent MS/MS scan method. The full scan MS spectra were collected in the 400$1,600 \mathrm{~m} / \mathrm{z}$ range with a maximum injection time of 100 milliseconds, a resolution of 120,000 at $200 \mathrm{~m} / \mathrm{z}$, spray voltage of 2 and AGC target of $3 \times 10^{6}$. Fragmentation of precursor ions was performed by high-energy C-trap dissociation (HCD) with the normalized collision energy of 27 $\mathrm{eV}$. MS/MS scans were acquired at a resolution of 15,000 at $\mathrm{m} / \mathrm{z} 200$ with an ion-target value of $1 \times 10^{5}$ and a maximum injection of 20 milliseconds. The dynamic exclusion was set at $15 \mathrm{~s}$ to avoid repeated scanning of identical peptides. Instrument was calibrated at the start of each batch run and then in every 72 hours using calibration mix solution (Thermo Scientific). The performance of the instrument was also evaluated routinely using complex E. coli digest purchased from Sigma.

Raw LC-MS/MS data were analyzed using MaxQuant(85) (v1.6.0.16) against the UniProt human protein database containing 40,707 proteins. The database search was performed with the precursor mass tolerance set to $10 \mathrm{ppm}$ and MS/MS fragment ions tolerance was set to 20 
ppm. Database search was performed with enzyme specificity for trypsin and LysC, allowing up to two missed cleavages. Oxidation of methionine and N-terminal acetylation were defined as a variable modification, and carbamidomethylation of cysteine was defined as a fixed modification for database searches. The 'unique plus razor peptides' were used for peptide quantitation. The false discovery rate (FDR) of both peptides and proteins identification was set at 0.01. Data were searched with 'match between runs' option. In the case of identified peptides that are shared between two proteins, these were combined and reported as one protein group. Proteins matching to the reverse database were filtered out.

Protein abundances were quantified using $\mathrm{IBAQ}(120)$ and transformed into relative concentrations relative to the lowest temperature $\left(37^{\circ} \mathrm{C}\right)$. Protein fold changes were normalized and melting curves were fitted following the protocol described by Savitski(83), Franken(84), and co-workers. The previously described normalization protocol(83) was adapted to fit the range of temperatures in our experiments. Melting curves were selected from both the vehicle and treatment groups where the fold change at $55^{\circ} \mathrm{C}$ was between 0.4 and 0.6 and the fold change at $60^{\circ} \mathrm{C}$ was less than 0.4 . Normalization was then applied as previously described(83). Following normalization, melting curves were fitted into the sigmoidal function(84):

$$
f(T)=\frac{1-p}{1+e^{-\left(\frac{a}{T}-b\right)}+p}
$$

where $T$ is the temperature, $a$ and $b$ are constants, and $p$ is the plateau as $T \rightarrow \infty$. The melting point $T_{m}$ is found using:

$$
T_{m}=\frac{a}{b-\ln \left(\frac{1-y}{y-p}\right)}
$$

at $f\left(T_{m}\right)=y=0.5$. The slope of the melting curve slope $=f^{\prime}\left(T_{\text {inflection }}\right)$ is found at the inflection point $T_{\text {inflection }}$ where $f^{\prime \prime}\left(T_{\text {inflection }}\right)=0$. Melting curves were determined using the nonlinear least-squares method as implemented in the SciPy package in Python. Proteins with poorly fitted curves were excluded if the parameters of the curve fit any of the following criteria: (i) vehicle or treatment curve with $R^{2}<0.8$, (ii) vehicle plateau $>0.3$, (iii) the number of points between $($ plateau $+0.1,0.9)<1$, and (iv) vehicle or treatment slope $>-0.06$. In total, 129 proteins were identified that passed all quality control filters. The shift in melting point $\Delta T_{m}$ was determined as:

$$
\Delta T_{m}=T_{m}^{\text {treatment }}-T_{m}^{\mathrm{vehicle}}
$$


A cutoff of $\Delta T_{m} \geq 3.0$ was used to identify proteins with significant thermal stability following compound treatment.

Gene Set Analysis. The STRING (Search Tool for the Retrieval of Interacting Genes/Proteins) database(86) incorporates protein-protein interactions from both direct physical interactions as well as indirect functional associations. STRING was used to integrate gene sets identified from protein target prediction using SVR-KB, differentially expressed genes identified from RNA sequencing, most similar gene signatures from L1000, and genes identified by thermal proteome profiling. A concatenated list of all HUGO gene symbols was used as input. Connections coming from text mining sources were excluded. Edges with confidence score $<0.7$ (high confidence) and genes with no edges in the subnetwork were excluded. The resulting subnetworks were visualized using Cytoscape(106).

General Chemistry. Preparative thin layer chromatography (PTLC) was performed on 20 $\times 20 \mathrm{~cm}$ plates (500-micron thick silica gel). Silica gel chromatography was performed on a Biotage Horizon flash chromatography system. ${ }^{1} \mathrm{H}$ NMR spectra were recorded on a Bruker Ascend TM 400 spectrometer at $400 \mathrm{MHz}$ at $298 \mathrm{~K}$, and the chemical shifts are given in parts per million (ppm) referenced to the residual proton signal of the deuterated solvents: $\mathrm{CHCl}_{3}$ at $\delta=$ 7.26 ppm and $\mathrm{CH}_{3} \mathrm{OH}$ or $\mathrm{CH}_{3} \mathrm{OD}$ at $\delta=3.30$ ppm. LC-MS spectra were taken on an Agilent Technologies 1260 Infinity or 6120 Quadrupole spectrometer. The mobile phase for the LC was acetontrile $(A)$ and water $(B)$ with $0.01 \%$ formic acid, and the eluent gradient was from $5-95 \% A$ in $6.0 \mathrm{~min}, 60-95 \% \mathrm{~A}$ in $5.0 \mathrm{~min}, 80-100 \% \mathrm{~A}$ in $5.0 \mathrm{~min}$ and $85-100 \% \mathrm{~A}$ in $10 \mathrm{~min}$ using a SBC18 $50 \mathrm{~mm} \times 4.6 \mathrm{~mm} \times 2.7 \mu \mathrm{m}$ capillary column. Mass spectra (MS) were measured by electrospray ion-mass spectroscopy (ESI). All temperatures are in ${ }^{\circ} \mathrm{C}$ unless otherwise noted.

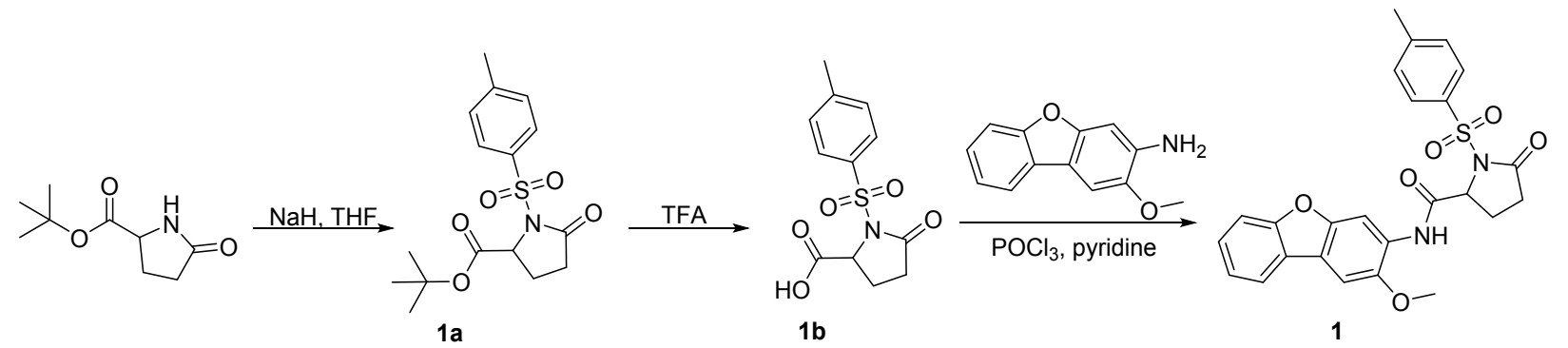

tert-butyl 5-oxo-1-tosylpyrrolidine-2-carboxylate (1a). To a solution of tert-butyl 5oxopyrrolidine-2-carboxylate (530 mg, $2.86 \mathrm{mmol}, 1.0 \mathrm{eq})$ in anhydrous THF $(10 \mathrm{~mL})$ at $0{ }^{\circ} \mathrm{C}, \mathrm{NaH}$ (343 mg, $8.58 \mathrm{mmol}, 3.0 \mathrm{eq}$ ) was added. The mixture was stirred for $15 \mathrm{~min}$, and 4- 
methylbenzene-1-sulfonyl chloride (600 mg, $3.15 \mathrm{mmol}, 1.1 \mathrm{eq}$ ) was added. The reaction mixture was stirred at room temperature for $2.5 \mathrm{~h}$. Water was added and the mixture was extracted with EA. The organic phase was washed with water, brine, and dried over $\mathrm{Na}_{2} \mathrm{SO}_{4}$. It was filtered and concentrated to give the desired product $(0.7 \mathrm{~g})$. ${ }^{1} \mathrm{H}$ NMR $\left(400 \mathrm{MHz}, \mathrm{CDCl}_{3}\right): \delta 7.97(\mathrm{~d}, J=8.4$ $\mathrm{Hz}, 2 \mathrm{H}), 7.33(\mathrm{~d}, J=8.1 \mathrm{~Hz}, 2 \mathrm{H}), 4.81-4.66(\mathrm{~m}, 1 \mathrm{H}), 2.60-2.49(\mathrm{~m}, 1 \mathrm{H}), 2.43(\mathrm{~s}, 3 \mathrm{H}), 2.42-$ $2.35(\mathrm{~m}, 2 \mathrm{H}), 2.09-2.01(\mathrm{~m}, 1 \mathrm{H}), 1.50(\mathrm{~s}, 9 \mathrm{H})$. LC-MS $(\mathrm{m} / \mathrm{z})=340[\mathrm{M}+\mathrm{H}]^{+}$.

5-oxo-1-tosylpyrrolidine-2-carboxylic acid (1b). TFA $(2.0 \mathrm{~mL})$ was added to a solution of $1 \mathrm{a}(0.7 \mathrm{~g}, 2.06 \mathrm{mmol}, 1.0 \mathrm{eq})$ in $\mathrm{DCM}(10.0 \mathrm{~mL})$, and the mixture was stirred at room temperature for $2.0 \mathrm{~h}$. The solution was concentrated to give a crude product $(0.5 \mathrm{~g})$. LC-MS $(\mathrm{m} / \mathrm{z})$ $=284[\mathrm{M}+\mathrm{H}]^{+}$.

\section{N-(2-methoxydibenzo[b,d]furan-3-yl)-5-oxo-1-tosylpyrrolidine-2-carboxamide}

To a solution of $1 \mathbf{b}(75 \mathrm{mg}, 0.26 \mathrm{mmol}, 1.0 \mathrm{eq})$ and 2-methoxydibenzo[b,d]furan-3-amine (56 mg, $0.26 \mathrm{mmol}, 1.0 \mathrm{eq})$ in pyridine $(2.0 \mathrm{~mL}), \mathrm{POCl}_{3}(10 \mathrm{drops})$ was added. The mixture was stirred at $65{ }^{\circ} \mathrm{C}$ overnight. Water was added, and the mixture was extracted with EA. The organic phase was washed with water, brine, and dried over $\mathrm{Na}_{2} \mathrm{SO}_{4}$. It was filtered and concentrated. The residue was purified with prep-TLC to give the desired product $(30 \mathrm{mg}) .{ }^{1} \mathrm{H}$ NMR $(400 \mathrm{MHz}$, $\left.\mathrm{CDCl}_{3}\right): \delta 8.66(\mathrm{~s}, 1 \mathrm{H}), 8.54(\mathrm{~s}, 1 \mathrm{H}), 7.93(\mathrm{~d}, J=8.4 \mathrm{~Hz}, 2 \mathrm{H}), 7.88(\mathrm{~d}, J=7.6 \mathrm{~Hz}, 1 \mathrm{H}), 7.57(\mathrm{~d}, J$ $=8.2 \mathrm{~Hz}, 1 \mathrm{H}), 7.46-7.40(\mathrm{~m}, 2 \mathrm{H}), 7.33(\mathrm{t}, J=7.5 \mathrm{~Hz}, 1 \mathrm{H}), 7.28(\mathrm{~d}, J=8.4 \mathrm{~Hz}, 2 \mathrm{H}), 4.96-4.91$ $(\mathrm{m}, 1 \mathrm{H}), 4.05(\mathrm{~s}, 3 \mathrm{H}), 2.81(\mathrm{dt}, J=20.4,8.7 \mathrm{~Hz}, 1 \mathrm{H}), 2.51-2.40(\mathrm{~m}, 5 \mathrm{H}), 2.34(\mathrm{t}, J=10.0 \mathrm{~Hz}$, 1H). LC-MS $(\mathrm{m} / \mathrm{z})=479[\mathrm{M}+\mathrm{H}]^{+}$.

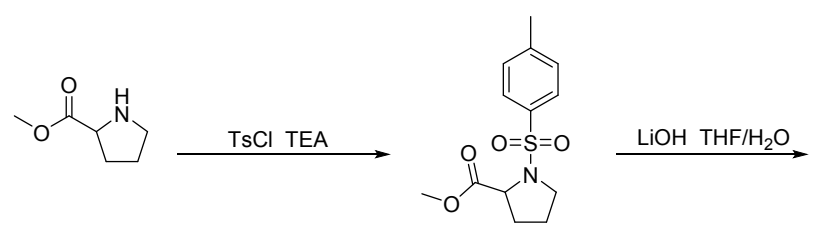

22a

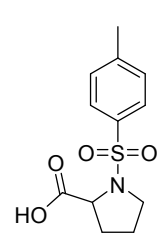

$22 b$
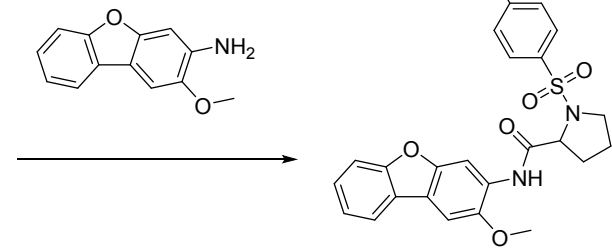

22

Methyl 1-tosylpyrrolidine-2-carboxylate (22a). In an oven-dried round-bottom flask, methyl pyrrolidine-2-carboxylate $(500 \mathrm{mg}, 3.02 \mathrm{mmol})$ was taken in $\mathrm{DCM}(10 \mathrm{~mL})$ at $0{ }^{\circ} \mathrm{C}$. To that solution $\mathrm{Et}_{3} \mathrm{~N}$ (915 mg, $9.06 \mathrm{mmol}$ ) was added dropwise over a period of $10 \mathrm{~min}$. After a few min of stirring at same temperature, $\mathrm{TsCl}(575 \mathrm{mg}, 3.02 \mathrm{mmol})$ was added portion-wise and reaction mixture was slowly brought to room temperature over a period of 2 hour (TLC showed the 
complete consumption of starting materials). The resulting mixture was extracted with DCM ( $3 \times$ $20 \mathrm{~mL}$ ) and the organic layers were combined and washed with brine (30 mL). The organic phase was dried over anhydrous sodium sulfate and concentrated under vacuum. The residue was applied onto a silica gel column with PE/EA (1:1) to afford the desired product $(750 \mathrm{~g}, 88 \%$ yield) as white solid. LC-MS (m/z) $284.1[\mathrm{M}+\mathrm{H}]^{+}$.

1-Tosylpyrrolidine-2-carboxylic acid (22b). To a solution of 22a (100 mg, $0.353 \mathrm{mmol})$ in $\mathrm{THF} / \mathrm{H}_{2} \mathrm{O}(4 \mathrm{~mL}: 1 \mathrm{~mL}), \mathrm{LiOH}(30 \mathrm{mg}, 0.707 \mathrm{mmol})$ was added. The resulting solution was stirred overnight at room temperature. The $\mathrm{pH}$ of the reaction solution was adjusted to a weak acidity with $1 \mathrm{~N}$ hydrochloric acid. The resulting mixture was extracted with ethyl acetate $(3 \times 20 \mathrm{~mL})$ and the organic layers were combined and washed with brine $(30 \mathrm{~mL})$. The organic phase was dried over anhydrous sodium sulfate and concentrated under vacuum. The residue was the desired product (100 mg crude) as white solid. LC-MS (m/z) $270.3[\mathrm{M}+\mathrm{H}]^{+}$.

N-(2-Methoxydibenzo[b,d]furan-3-yl)-1-tosylpyrrolidine-2-carboxamide (22). Into a $50 \mathrm{~mL}$ round-bottom flask purged was placed a solution of 22a (63 mg crude, $0.235 \mathrm{mmol}$ ) in DCM (3 ml), and then DIEA (91 mg, $0.704 \mathrm{mmol}$ ), 2-methoxydibenzo[b,d]furan-3-amine (50 mg, $0.235 \mathrm{mmol})$ and HATU $(107 \mathrm{mg}, 0.282 \mathrm{mmol})$ were added at $0{ }^{\circ} \mathrm{C}$. The resulting mixture was stirred at room temperature overnight. The mixture was diluted by DCM $(10 \mathrm{~mL})$, and the solution was washed with brine, and dried over anhydrous sodium sulfate. The solvent was evaporated under reduced pressure. The residue was purified by prep-HPLC to afford the desired product 22 (8 mg, 7\% yield) as white solid. ${ }^{1} \mathrm{H}$ NMR (400 MHz, $\left.\mathrm{CDCl}_{3}\right): \delta 9.59(\mathrm{~s}, 1 \mathrm{H}), 8.71(\mathrm{~s}, 1 \mathrm{H}), 7.87$ (d, $J=7.6 \mathrm{~Hz}, 1 \mathrm{H}), 7.80(\mathrm{~d}, J=8.4 \mathrm{~Hz}, 2 \mathrm{H}), 7.56(\mathrm{~d}, J=8.0 \mathrm{~Hz}, 1 \mathrm{H}), 7.29-7.42(\mathrm{~m}, 5 \mathrm{H}), 4.30-4.33$ $(\mathrm{m}, 1 \mathrm{H}), 4.07(\mathrm{~s}, 3 \mathrm{H}), 3.61-3.65(\mathrm{~m}, 1 \mathrm{H}), 3.27-3.29(\mathrm{~m}, 1 \mathrm{H}), 2.45(\mathrm{~s}, 3 \mathrm{H}), 2.32-2.36(\mathrm{~m}, 1 \mathrm{H}), 1.68-$ $1.70(\mathrm{~m}, 1 \mathrm{H}), 1.60-1.67(\mathrm{~m}, 2 \mathrm{H}) .{ }^{13} \mathrm{C}$ NMR $\left(400 \mathrm{MHz}, \mathrm{CDCl}_{3}\right): \delta$ 169.1, 156.8, 150.8, 145.6, 144.5, 133.2, 130.0, 128.0, 127.4, 126.2, 124.6, 122.4, 119.8, 118.9, 111.7, 103.3, 101.6, 63.4, 57.0, 49.8, 30.0, 24.5, 21.6. LC-MS (m/z) $465.1[\mathrm{M}+\mathrm{H}]^{+}$.

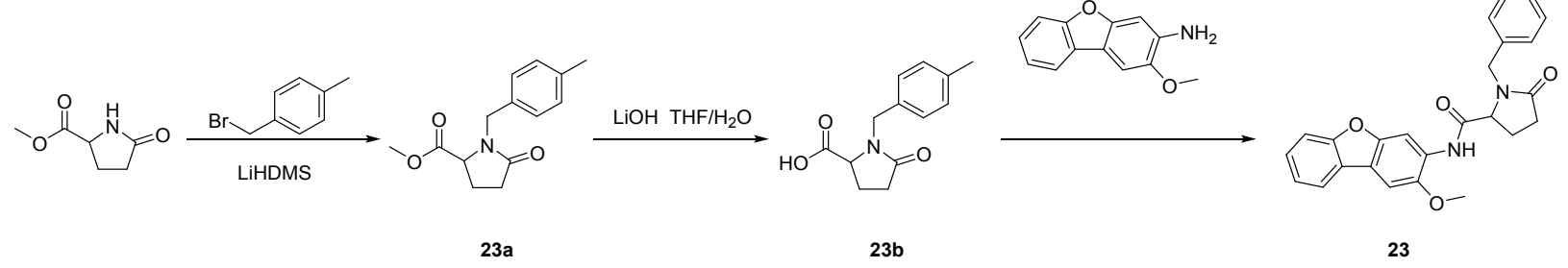


Methyl 1-(4-methylbenzyl)-5-oxopyrrolidine-2-carboxylate (23a). In an oven-dried round-bottom flask, methyl 5-oxopyrrolidine-2-carboxylate $(500 \mathrm{mg}, 3.02 \mathrm{mmol})$ was taken in dry THF $(10 \mathrm{~mL})$ and cooled to $-30^{\circ} \mathrm{C}$ under $\mathrm{N}_{2}$. To the reaction solution was added dropwise LiHMDS (701 $\mathrm{mg}, 4.19 \mathrm{mmol}$ ) at $-30^{\circ} \mathrm{C}$, and the mixture was stirred at this temperature for $1 \mathrm{~h}$. A solution of 1-(bromomethyl)-4-methylbenzene $(712 \mathrm{mg}, 3.84 \mathrm{mmol})$ in THF was added dropwise to the reaction solution at $-30^{\circ} \mathrm{C}$. After naturally warming to room temperature, the resulting solution was stirred at room temperature for $4 \mathrm{~h}$. The resulting mixture was diluted with ethyl acetate and the organic layers were washed with water. The organic phase was dried over anhydrous sodium sulfate and concentrated under vacuum. The residue was applied onto a silica gel column with PE/EA (1:1 ) to afford the desired product (420 mg, 48\% yield) as white solid. LC-MS (m/z) = $248.1[\mathrm{M}+\mathrm{H}]^{+}$.

1-(4-Methylbenzyl)-5-oxopyrrolidine-2-carboxylic acid (23b). To a solution of 23a (420 $\mathrm{mg}, 1.70 \mathrm{mmol})$ in $\mathrm{THF} / \mathrm{H}_{2} \mathrm{O}(4 \mathrm{~mL}: 1 \mathrm{~mL})$ was added $\mathrm{LiOH}(143 \mathrm{mg}, 3.40 \mathrm{mmol})$. The resulting solution was stirred overnight at room temperature. The $\mathrm{pH}$ of the reaction solution was adjusted to a weak acidity with $1 \mathrm{~N}$ hydrochloric acid. The resulting mixture was extracted with ethyl acetate $(3 \times 20 \mathrm{~mL})$ and the organic layers were combined and washed with brine $(30 \mathrm{~mL})$. The organic phase was dried over anhydrous sodium sulfate and concentrated under vacuum. The residue was the desired product (230 mg crude) as white solid. LC-MS $(\mathrm{m} / \mathrm{z})=234.2[\mathrm{M}+\mathrm{H}]^{+}$.

\section{N-(2-Methoxydibenzo[b,d]furan-3-yl)-1-(4-methylbenzyl)-5-oxopyrrolidine-2-}

carboxamide (23). Into a $50 \mathrm{~mL}$ round -bottom flask purged was placed a solution of $\mathbf{2 3 b}$ (55 mg crude, $0.235 \mathrm{mmol})$ in DCM (3 ml), and then DIEA (182 mg, $0.704 \mathrm{mmol})$, 2methoxydibenzo[b,d]furan-3-amine (50 mg, $0.469 \mathrm{mmol}$ ) and HATU (107 mg, $0.282 \mathrm{mmol}$ ) were added at $0{ }^{\circ} \mathrm{C}$. The resulting mixture was stirred at room temperature overnight. The mixture was diluted by DCM (10 mL), and the solution was washed with brine, and dried over anhydrous sodium sulfate. The solvent was evaporated under reduced pressure. The residue was purified by prep-HPLC to afford the desired product (15 mg, 15\% yield) as white solid. ${ }^{1} \mathrm{H}$ NMR (400 MHz, $\left.\mathrm{CDCl}_{3}\right): \delta 8.68(\mathrm{~s}, 1 \mathrm{H}), 8.11(\mathrm{~s}, 1 \mathrm{H}), 7.87(\mathrm{~d}, J=7.2 \mathrm{~Hz}, 1 \mathrm{H}), 7.56(\mathrm{~d}, J=8.0 \mathrm{~Hz}, 1 \mathrm{H}), 7.32-7.44$ $(\mathrm{m}, 3 \mathrm{H}), 7.10-7.16(\mathrm{~m}, 4 \mathrm{H}), 5.13-5.17(\mathrm{~m}, 1 \mathrm{H}), 3.94-4.02(\mathrm{~m}, 5 \mathrm{H}), 2.67-2.74(\mathrm{~m}, 1 \mathrm{H}), 2.44-2.52$ $(\mathrm{m}, 1 \mathrm{H}), 2.30-2.41(\mathrm{~m}, 1 \mathrm{H}), 2.29(\mathrm{~s}, 3 \mathrm{H}), 2.17-2.23(\mathrm{~m}, 1 \mathrm{H}) .{ }^{13} \mathrm{C} \mathrm{CMR}\left(400 \mathrm{MHz}, \mathrm{CDCl}_{3}\right): \delta 175.6$, $169.2,156.8,150.7,144.9,137.7,132.6,129.5,128.7,126.5,126.4,124.4,122.5,119.8,119.2$, $111.8,103.8,101.0,61.5,56.4,45.6,29.8,23.6,21.1$. LC-MS $(\mathrm{m} / \mathrm{z})=429.2[\mathrm{M}+\mathrm{H}]^{+}$. 

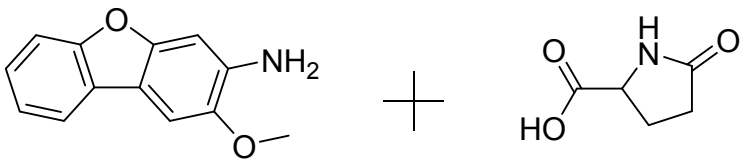

HATU DIEA

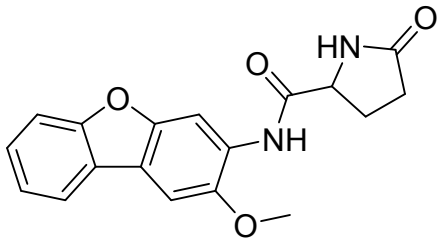

24

N-(2-Methoxydibenzo[b,d]furan-3-yl)-5-oxopyrrolidine-2-carboxamide (24). Into a 50 $\mathrm{mL}$ round -bottom flask purged was placed a solution of pyroglutamic acid (61 $\mathrm{mg}$ crude, 0.469 $\mathrm{mmol}$ ) in DCM (6 ml), and then DIEA (182 mg, $1.41 \mathrm{mmol})$, 2-methoxydibenzo[b,d]furan-3-amine $(100 \mathrm{mg}, 0.469 \mathrm{mmol})$ and HATU $(214 \mathrm{mg}, 0.563 \mathrm{mmol})$ were added at $0{ }^{\circ} \mathrm{C}$. The resulting mixture was stirred at room temperature overnight. The mixture was diluted by DCM $(20 \mathrm{~mL})$, and the solution was washed with brine, and dried over anhydrous sodium sulfate. The solvent was evaporated under reduced pressure. The residue was purified by prep-HPLC to afford the desired product (15 mg, 10\% yield) as white solid. ${ }^{1} \mathrm{H}$ NMR (400 MHz, DMSO- $\left.d_{6}\right): \delta 9.43(\mathrm{~s}, 1 \mathrm{H}), 8.46$ (s, $1 \mathrm{H}), 8.09(\mathrm{~d}, J=7.6 \mathrm{~Hz}, 1 \mathrm{H}), 7.99(\mathrm{~s}, 1 \mathrm{H}), 7.84(\mathrm{~s}, 1 \mathrm{H}), 7.65(\mathrm{~d}, J=8.4 \mathrm{~Hz}, 1 \mathrm{H}), 7.46(\mathrm{t}, J=8.0$ $\mathrm{Hz}, 1 \mathrm{H}), 7.37(\mathrm{t}, J=7.6 \mathrm{~Hz}, 1 \mathrm{H}), 4.44-4.47(\mathrm{~m}, 1 \mathrm{H}), 3.99(\mathrm{~s}, 3 \mathrm{H}), 2.33-2.40(\mathrm{~m}, 1 \mathrm{H}), 2.21-2.30(\mathrm{~m}$, $1 \mathrm{H}), 2.10-2.18(\mathrm{~m}, 1 \mathrm{H}), 2.02-2.07(\mathrm{~m}, 1 \mathrm{H}) .{ }^{13} \mathrm{C}$ CMR (400 MHz, DMSO-d $\left.\mathrm{d}_{6}\right): \delta 178.1,172.3,156.4$, 150.0, 146.6, 127.6, 127.1, 124.6, 123.3, 121.1, 119.1, 112.0, 104.4, 103.3, 57.1, 56.7, 29.6, 26.0. LC-MS $\left(E S^{+}\right)(\mathrm{m} / \mathrm{z})=325.1[\mathrm{M}+\mathrm{H}]^{+}$.
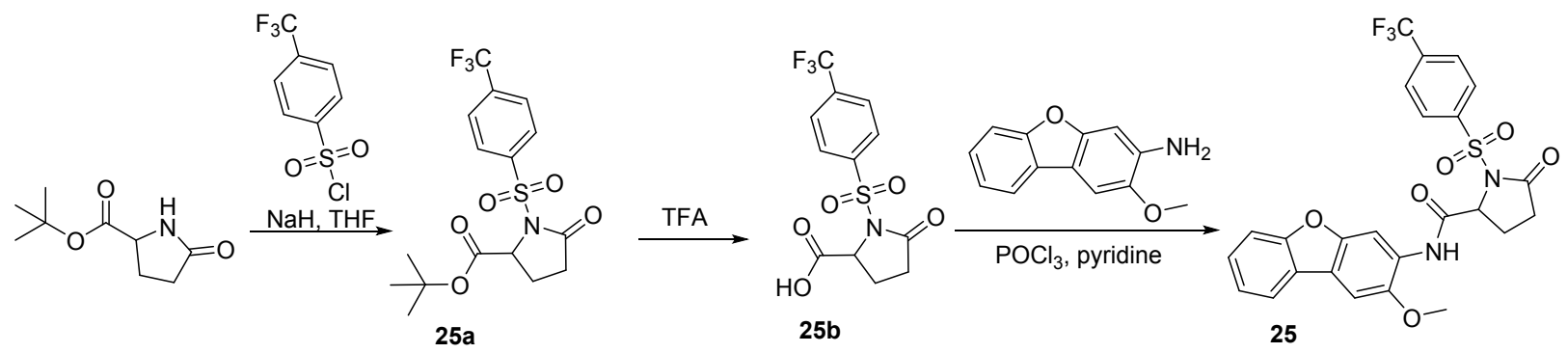

tert-butyl 5-oxo-1-((4-(trifluoromethyl)phenyl)sulfonyl)pyrrolidine-2

-carboxylate (25a). To a solution of tert-butyl 5-oxopyrrolidine-2-carboxylate (509 mg, $2.75 \mathrm{mmol}, 1.0 \mathrm{eq})$ in anhydrous THF $(10 \mathrm{~mL})$ at $0{ }^{\circ} \mathrm{C}, \mathrm{NaH}(330 \mathrm{mg}, 8.24 \mathrm{mmol}, 3.0 \mathrm{eq})$ was added. The mixture was stirred for $15 \mathrm{~min}$, and 4-(trifluoromethyl)benzene-1-sulfonyl chloride (739 $\mathrm{mg}, 3.02 \mathrm{mmol}, 1.1 \mathrm{eq}$ ) was added. The reaction mixture was stirred at room temperature for $2 \mathrm{~h}$. Water was added and the mixture was extracted with EA. The organic phase was washed with water, brine, and dried over $\mathrm{Na}_{2} \mathrm{SO}_{4}$. It was filtered and concentrated to give the desired product 
(0.5 g). ${ }^{1} \mathrm{H}$ NMR $\left(400 \mathrm{MHz}, \mathrm{CDCl}_{3}\right): \delta 8.24$ (d, J=8.3 Hz, 2H), 7.80 (d, J = 8.4 Hz, 2H), 4.79 (dd, $J=9.0,2.6 \mathrm{~Hz}, 1 \mathrm{H}), 2.61-2.38(\mathrm{~m}, 3 \mathrm{H}), 2.14-2.02(\mathrm{~m}, 1 \mathrm{H}), 1.51(\mathrm{~s}, 9 \mathrm{H})$. LC-MS $(\mathrm{m} / \mathrm{z})=394$ $[\mathrm{M}+\mathrm{H}]^{+}$.

5-oxo-1-((4-(trifluoromethyl)phenyl)sulfonyl)pyrrolidine-2-carboxylic acid (25b). To a solution of $25 \mathrm{a}(81 \mathrm{mg}, 0.206 \mathrm{mmol}, 1.0 \mathrm{eq})$ in DCM $(6.0 \mathrm{~mL})$, TFA (1.5 mL) was added. The mixture was stirred at room temperature for $2 \mathrm{~h}$. It was concentrated to obtain a crude product without purification. LC-MS $(\mathrm{m} / \mathrm{z})=338[\mathrm{M}+\mathrm{H}]^{+}$.

\section{N-(2-methoxydibenzo[b,d]furan-3-yl)-5-oxo-1-((4-}

(trifluoromethyl)phenyl)sulfonyl)pyrrolidine-2-carboxamide (25). To a solution of 25b (69 $\mathrm{mg}, 0.206 \mathrm{mmol}, 1.0 \mathrm{eq}$ ) and 2-methoxydibenzo[b,d]furan-3-amine (55 mg, $0.206 \mathrm{mmol}, 1.0 \mathrm{eq}$ ) in pyridine $(2.0 \mathrm{~mL}), \mathrm{POCl}_{3}\left(10\right.$ drops) was added. The mixture was stirred at $65{ }^{\circ} \mathrm{C}$ overnight. Water was added and the mixture was extracted with EA. The organic phase was washed with water, brine, and dried over $\mathrm{Na}_{2} \mathrm{SO}_{4}$. It was filtered and concentrated. The residue was purified with prep-TLC to give the desired product (22 mg). ${ }^{1} \mathrm{H} \mathrm{NMR}\left(400 \mathrm{MHz}, \mathrm{CDCl}_{3}\right): \delta 8.64(\mathrm{~s}, 1 \mathrm{H})$, $8.44(\mathrm{~s}, 1 \mathrm{H}), 8.22(\mathrm{~d}, J=8.3 \mathrm{~Hz}, 2 \mathrm{H}), 7.87(\mathrm{~d}, J=7.7 \mathrm{~Hz}, 1 \mathrm{H}), 7.78(\mathrm{~d}, J=8.4 \mathrm{~Hz}, 2 \mathrm{H}), 7.57(\mathrm{~d}, J$ $=8.2 \mathrm{~Hz}, 1 \mathrm{H}), 7.47-7.39(\mathrm{~m}, 2 \mathrm{H}), 7.33(\mathrm{dd}, J=10.9,4.0 \mathrm{~Hz}, 1 \mathrm{H}), 5.00(\mathrm{dd}, J=8.4,2.3 \mathrm{~Hz}, 1 \mathrm{H})$, $4.03(\mathrm{~s}, 3 \mathrm{H}), 2.80$ (ddd, $J=20.7,10.8,6.7 \mathrm{~Hz}, 1 \mathrm{H}), 2.62-2.21(\mathrm{~m}, 5 \mathrm{H})$. LC-MS $(\mathrm{m} / \mathrm{z})=533$ $[\mathrm{M}+\mathrm{H}]^{+}$.
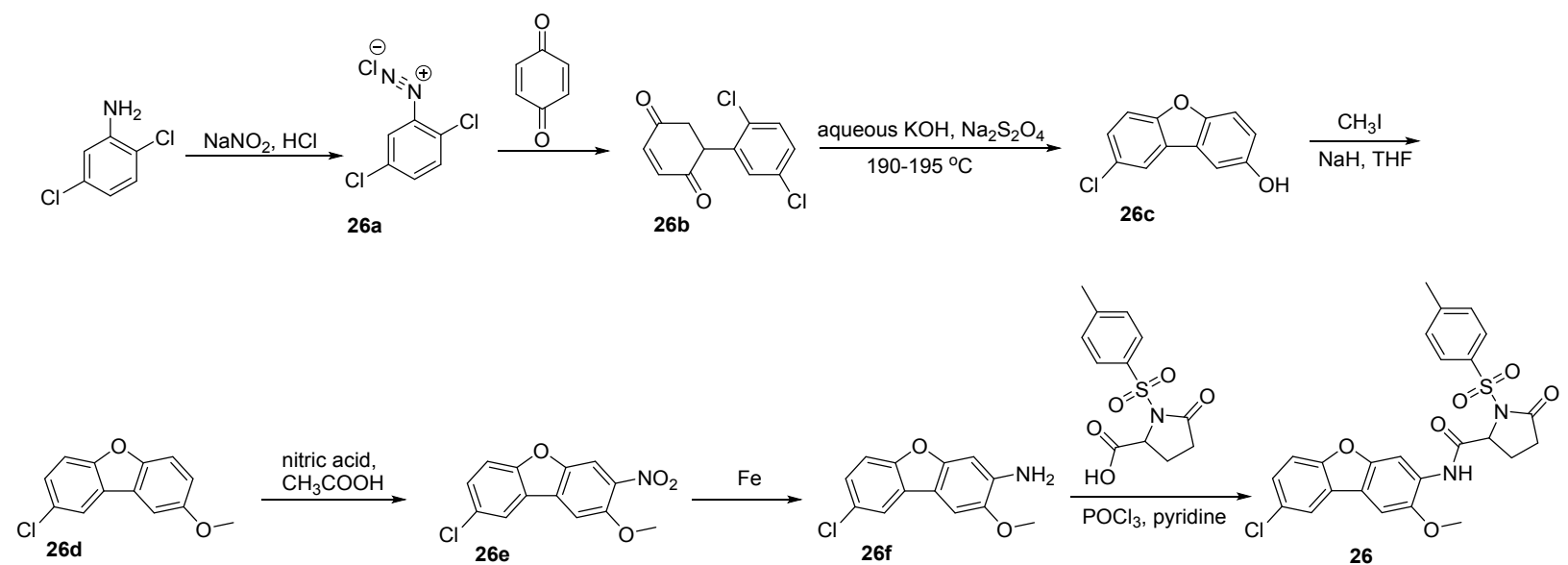

2,5-dichlorobenzenediazonium chloride (26a). 2,5-dichloroaniline (5.0 g, 30.86 mmol, $1.0 \mathrm{eq})$ was dissolved in concentrated hydrochloric acid $(8.75 \mathrm{~mL})$ and ice $(25 \mathrm{~g})$ was added. When the mixture was cooled to $0{ }^{\circ} \mathrm{C}$, saturated sodium nitrite $(2.56 \mathrm{~g}, 37.04 \mathrm{mmol}, 1.2 \mathrm{eq})$ 
aqueous solution was added while keeping the temperature below $5{ }^{\circ} \mathrm{C}$. After 15 min, resinous sediment was filtered, and the obtained diazonium salt solution was used into next step.

2',5'-dichloro-1,6-dihydro-[1,1'-biphenyl]-2,5-dione (26b). The diazonium salt solution 26a was added dropwise into quinone (3.34 g, $30.86 \mathrm{mmol}, 1.0 \mathrm{eq})$, AcONa (6.33 g, $77.15 \mathrm{mmol}$, $2.5 \mathrm{eq})$, and water $(120 \mathrm{~mL})$ suspension while keeping the temperature at $15-20{ }^{\circ} \mathrm{C}$. The reaction mixture was stirred for $2 \mathrm{~h}$. The resulting solid was filtered.

8-chlorodibenzo[b,d]furan-2-ol (26c). 26b (2.0 g, $7.84 \mathrm{mmol}, 1.0 \mathrm{eq})$ was mixed with potassium hydroxide (440 mg, $7.84 \mathrm{mmol}, 1.0 \mathrm{eq}$ ), sodium hydrosulphite (195 mg, $0.784 \mathrm{mmol}$, $0.1 \mathrm{eq})$, and water $(142 \mathrm{mg}, 7.84 \mathrm{mmol}, 1.0 \mathrm{eq})$ and heated to about $120^{\circ} \mathrm{C}$. Additional potassium hydroxide ( $880 \mathrm{mg}, 15.68 \mathrm{mmol}, 2.0 \mathrm{eq}$ ) was added while raising the temperature. On further heating, liquefaction set slowly in at $170{ }^{\circ} \mathrm{C}$, and at $195^{\circ} \mathrm{C}$. The whole melt became thinly liquid and boiled. As soon as foaming was no longer observed, the reaction was finished. The melt was introduced into water, and extracted with EA. The organic layer was washed with water and brine, and dried with $\mathrm{Na}_{2} \mathrm{SO}_{4}$. It was filtered and concentrated. The residue was purified with silica gel column chromatography (PE:EA = 10:1-5:1), to give an orange solid $(1.05 \mathrm{~g}) .{ }^{1} \mathrm{H}-\mathrm{NMR}(400 \mathrm{MHz}$, $\left.\mathrm{CDCl}_{3}\right): \delta 7.83(\mathrm{~d}, J=1.6 \mathrm{~Hz}, 1 \mathrm{H}), 7.46-7.37(\mathrm{~m}, 3 \mathrm{H}), 7.32-7.26(\mathrm{~m}, 1 \mathrm{H}), 7.00-6.97(\mathrm{~m}, 1 \mathrm{H}), 4.83$ $(\mathrm{s}, 1 \mathrm{H})$. LC-MS $(\mathrm{m} / \mathrm{z})=219[\mathrm{M}+\mathrm{H}]^{+}$.

2-chloro-8-methoxydibenzo[b,d]furan (26d). To a solution of $26 \mathrm{c}(1.05 \mathrm{~g}, 4.82 \mathrm{mmol}$, $1.0 \mathrm{eq})$ in anhydrous THF (15 mL), NaH (386 mg, $9.64 \mathrm{mmol}, 2.0 \mathrm{eq})$ was added under $0{ }^{\circ} \mathrm{C}$. The mixture was stirred for $15 \mathrm{~min}$, and $\mathrm{CH}_{3} \mathrm{l}(1.37 \mathrm{~g}, 9.64 \mathrm{mmol}, 2.0 \mathrm{eq})$ was added. The reaction mixture was stirred at room temperature for $3 \mathrm{~h}$. The mixture was diluted with water and extracted with EA. The organic phase was washed with water, brine, and dried over $\mathrm{Na}_{2} \mathrm{SO}_{4}$. It was filtered and concentrated to obtain the desired product $(1.35 \mathrm{~g})$. LC-MS $(\mathrm{m} / \mathrm{z})=233[\mathrm{M}+\mathrm{H}]^{+}$.

8-chloro-2-methoxy-3-nitrodibenzo[b,d]furan (26e). 26d (230 mg, 0.92 mmol, 1.0 eq) was dissolved in acetic acid $(3.0 \mathrm{~mL})$, and nitric acid $(70 \mathrm{mg}, 1.12 \mathrm{mmol}, 1.2 \mathrm{eq})$ was added. The mixture was stirred at room temperature overnight. The reaction mixture was mixed with water, and extracted with EA. The organic phase was washed with water, brine, and dried over $\mathrm{Na}_{2} \mathrm{SO}_{4}$. It was filtered and concentrated to obtain the crude product.

8-chloro-2-methoxydibenzo[b,d]furan-3-amine (26f). To crude 26e (255 mg, 0.92 $\mathrm{mmol}, 1.0 \mathrm{eq})$ in ethanol $(12.0 \mathrm{~mL})$ and aqueous $\mathrm{NH}_{3} \mathrm{Cl}(12.0 \mathrm{~mL})$, iron powder $(412 \mathrm{mg}, 7.36$ $\mathrm{mmol}, 8.0 \mathrm{eq}$ ) was added. The mixture was stirred under reflux for $2 \mathrm{~h}$. The reaction mixture was mixed with water, and extracted with EA. The organic phase was washed with water, brine, and 
dried over $\mathrm{Na}_{2} \mathrm{SO}_{4}$. It was filtered and concentrated to obtain the crude product that was purified with prep-TLC to give the desired product (94 mg, yield 41.4\%). LC-MS $(\mathrm{m} / \mathrm{z})=248[\mathrm{M}+\mathrm{H}]^{+}$.

\section{N-(8-chloro-2-methoxydibenzo[b,d]furan-3-yl)-5-oxo-1-tosylpyrrolidine-2-}

carboxamide (26). To a mixture of $26 f(94 \mathrm{mg}, 0.38 \mathrm{mmol}, 1.0 \mathrm{eq})$ and 5-oxo-1-tosylpyrrolidine2-carboxylic acid (129 mg, $0.46 \mathrm{mmol}, 1.2 \mathrm{eq}$ ) in pyridine (4.0 mL), $\mathrm{POCl}_{3}$ (20 drops) was added. The mixture was stirred at $65{ }^{\circ} \mathrm{C}$ for $5 \mathrm{~h} .5 \%$ citric acid was added and the mixture was extracted with EA. The organic phase was washed with water, brine, and dried over $\mathrm{Na}_{2} \mathrm{SO}_{4}$. It was filtered and concentrated. The residue was purified with prep-TLC to give the desired product $(25 \mathrm{mg})$. ${ }^{1} \mathrm{H}$ NMR (400 MHz, CDCl $): \delta 8.66(\mathrm{~s}, 1 \mathrm{H}), 8.58(\mathrm{~s}, 1 \mathrm{H}), 7.95(\mathrm{~d}, J=8.3 \mathrm{~Hz}, 2 \mathrm{H}), 7.80$ (d, J = 2.1 $\mathrm{Hz}, 1 \mathrm{H}), 7.46(\mathrm{~d}, J=8.7 \mathrm{~Hz}, 1 \mathrm{H}), 7.36(\mathrm{dd}, J=8.7,2.1 \mathrm{~Hz}, 1 \mathrm{H}), 7.31(\mathrm{~d}, J=3.4 \mathrm{~Hz}, 2 \mathrm{H}), 7.29$ (s, $1 \mathrm{H}), 4.97(\mathrm{dd}, J=8.3,2.1 \mathrm{~Hz}, 1 \mathrm{H}), 4.02(\mathrm{~d}, J=4.7 \mathrm{~Hz}, 3 \mathrm{H}), 2.80(\mathrm{~m}, 1 \mathrm{H}), 2.50-2.40(\mathrm{~m}, 5 \mathrm{H})$, $2.36-2.28(\mathrm{~m}, 1 \mathrm{H})$. LC-MS $(\mathrm{m} / \mathrm{z})=513[\mathrm{M}+\mathrm{H}]^{+}$.
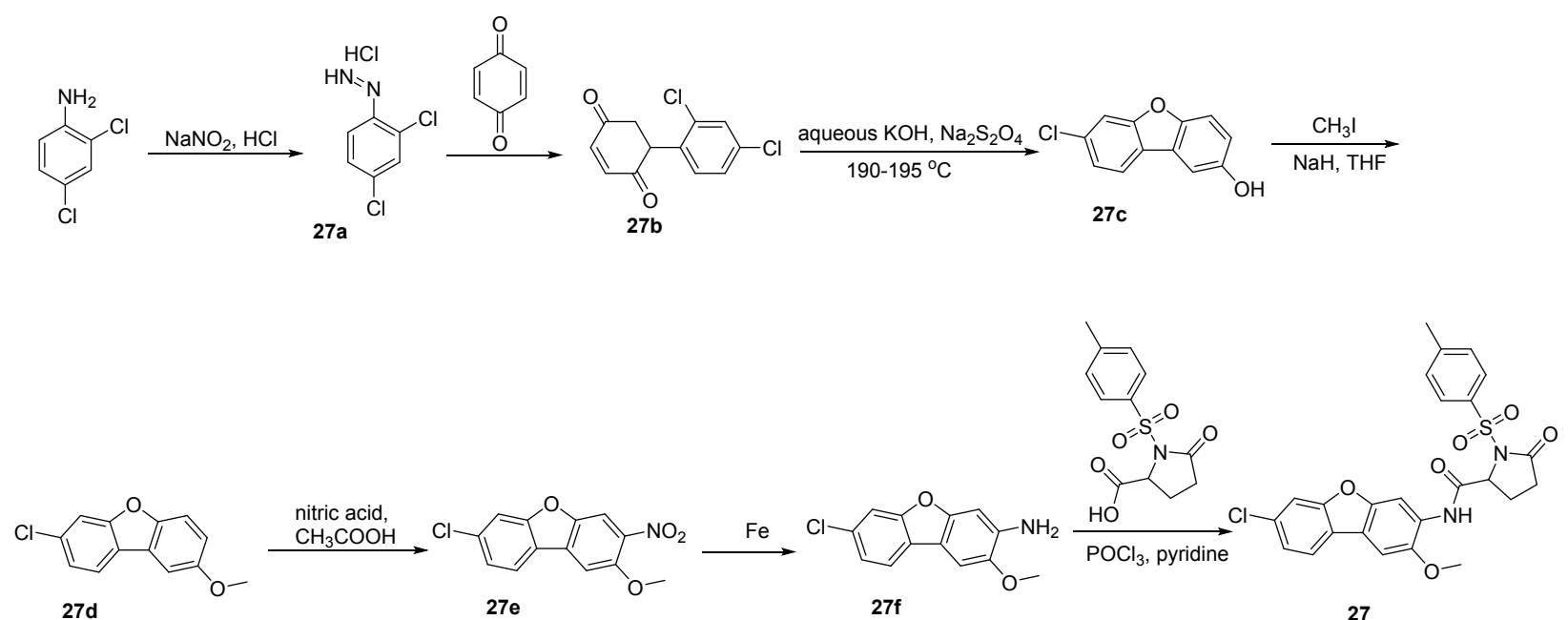

2,4-dichlorobenzenediazonium chloride (27a). 2,4-dichloroaniline (2.0 g, 12.35 mmol, $1.0 \mathrm{eq})$ was dissolved in concentrated hydrochloric acid $(3.5 \mathrm{~mL})$ and ice $(10 \mathrm{~g})$ was added. When the mixture was cooled to $0^{\circ} \mathrm{C}$, saturated sodium nitrite $(1.02 \mathrm{~g}, 14.81 \mathrm{mmol}, 1.2 \mathrm{eq})$ aqueous solution was added while keeping the temperature below $5^{\circ} \mathrm{C}$. After $15 \mathrm{~min}$, resinous sediment was filtered, and the resulting diazonium salt solution was used in the next step.

2',4'-dichloro-1,6-dihydro-[1,1'-biphenyl]-2,5-dione (27b). The diazonium salt solution was added dropwise into quinone (1.33 g, $12.3 \mathrm{mmol}, 1.0 \mathrm{eq})$, AcONa (2.5 g, $30.75 \mathrm{mmol}, 2.5$ eq), and water $(50 \mathrm{~mL})$ suspension while keeping the temperature at $15-20{ }^{\circ} \mathrm{C}$. The reaction mixture was stirred for $2 \mathrm{~h}$. The resulting solid was filtered. 
7-chlorodibenzo[b,d]furan-2-ol (27c). 27b (1.0 g, $3.92 \mathrm{mmol}, 1.0 \mathrm{eq})$ was mixed with potassium hydroxide $(220 \mathrm{mg}, 3.92 \mathrm{mmol}, 1.0 \mathrm{eq})$, sodium hydrosulphite $(97 \mathrm{mg}, 0.392 \mathrm{mmol}$, $0.1 \mathrm{eq})$, and water $(7.1 \mathrm{mg}, 3.92 \mathrm{mmol}, 1.0 \mathrm{eq})$ and heated to about $120{ }^{\circ} \mathrm{C}$. Additional potassium hydroxide (440 mg, $7.84 \mathrm{mmol}, 2.0 \mathrm{eq}$ ) was added while raising the temperature. On further heating, liquefaction set slowly in at $170{ }^{\circ} \mathrm{C}$, and at $195^{\circ} \mathrm{C}$. The whole melt became thinly liquid and boiled. As soon as foaming was no longer observed, the reaction was finished. The melt was added into water, and the mixture was extracted with EA. The organic layer was washed with water and brine, and dried with $\mathrm{Na}_{2} \mathrm{SO}_{4}$. It was filtered and concentrated. The residue was purified with silica gel column chromatography (PE:EA = 10:1-5:1), to give an orange solid (110 mg). ${ }^{1} \mathrm{H}$ $\operatorname{NMR}\left(400 \mathrm{MHz}, \mathrm{CDCl}_{3}\right): \delta 7.78(\mathrm{~d}, J=8.3 \mathrm{~Hz}, 1 \mathrm{H}), 7.54(\mathrm{~d}, J=1.7 \mathrm{~Hz}, 1 \mathrm{H}), 7.42(\mathrm{~d}, J=8.8 \mathrm{~Hz}$, $1 \mathrm{H}), 7.33(\mathrm{~d}, J=2.5 \mathrm{~Hz}, 1 \mathrm{H}), 7.30(\mathrm{dd}, J=8.3,1.8 \mathrm{~Hz}, 1 \mathrm{H}), 6.96(\mathrm{dd}, J=8.8,2.6 \mathrm{~Hz}, 1 \mathrm{H}), 4.77$ $(\mathrm{s}, 1 \mathrm{H}) . \mathrm{LC}-\mathrm{MS}(\mathrm{m} / \mathrm{z})=219[\mathrm{M}+\mathrm{H}]^{+}$.

7-chloro-2-methoxydibenzo[b,d]furan (27d). To a solution of $27 \mathrm{c}(110 \mathrm{mg}, 0.505 \mathrm{mmol}$, $1.0 \mathrm{eq})$ in anhydrous THF (15 mL), NaH (24 mg, $1.01 \mathrm{mmol}, 2.0 \mathrm{eq})$ was added under $0{ }^{\circ} \mathrm{C}$. The mixture was stirred for $10 \mathrm{~min}$, and $\mathrm{CH}_{3} \mathrm{l}(143 \mathrm{mg}, 1.01 \mathrm{mmol}, 2.0 \mathrm{eq}$ ) was added. The reaction mixture was stirred at room temperature for $1 \mathrm{~h}$. Water was added, and the mixture was extracted with EA. The organic phase was washed with water, brine, and dried over $\mathrm{Na}_{2} \mathrm{SO}_{4}$. It was filtered and concentrated to obtain the desired product (130 mg). ${ }^{1} \mathrm{H} \mathrm{NMR}\left(400 \mathrm{MHz}, \mathrm{CDCl}_{3}\right): \delta 7.81$ (d, $J=8.3 \mathrm{~Hz}, 1 \mathrm{H}), 7.55(\mathrm{~d}, J=1.7 \mathrm{~Hz}, 1 \mathrm{H}), 7.46(\mathrm{~d}, J=8.9 \mathrm{~Hz}, 1 \mathrm{H}), 7.37(\mathrm{~d}, J=2.6 \mathrm{~Hz}, 1 \mathrm{H}), 7.31$ $(\mathrm{dd}, J=8.3,1.8 \mathrm{~Hz}, 1 \mathrm{H}), 7.05(\mathrm{dd}, J=8.9,2.6 \mathrm{~Hz}, 1 \mathrm{H}), 3.91(\mathrm{~s}, 3 \mathrm{H}) . \mathrm{LC}-\mathrm{MS}(\mathrm{m} / \mathrm{z})=233[\mathrm{M}+\mathrm{H}]^{+}$.

7-chloro-2-methoxy-3-nitrodibenzo[b,d]furan (27e). To a solution of $\mathbf{2 7 d}$ (130 $\mathrm{mg}, 0.56$ $\mathrm{mmol}, 1.0 \mathrm{eq})$ in acetic acid $(3.0 \mathrm{~mL})$, nitric acid $(70 \mathrm{mg}, 0.67 \mathrm{mmol}, 1.2 \mathrm{eq})$ was added. The mixture was stirred at room temperature overnight. The reaction mixture was mixed with water, and extracted with EA. The organic phase was washed with water, brine, and dried over $\mathrm{Na}_{2} \mathrm{SO}_{4}$. It was filtered and concentrated to obtain the crude product used in the next step without purification.

7-chloro-2-methoxydibenzo[b,d]furan-3-amine (27f). To a solution of crude 27 e (155 $\mathrm{mg}, 0.56 \mathrm{mmol}, 1.0 \mathrm{eq})$ in ethanol $(6.0 \mathrm{~mL})$ and aqueous $\mathrm{NH}_{3} \mathrm{Cl}(6.0 \mathrm{~mL})$, iron powder $(251 \mathrm{mg}$, $4.48 \mathrm{mmol}, 8.0 \mathrm{eq}$ ) was added. The mixture was stirred under reflux for $2 \mathrm{~h}$. The reaction mixture was mixed with water, and extracted with EA. The organic phase was washed with water, brine, and dried over $\mathrm{Na}_{2} \mathrm{SO}_{4}$. It was filtered and concentrated. The residue was purified with prep-TLC to give the desired product (45 mg). ${ }^{1} \mathrm{H}$ NMR (400 MHz, $\left.\mathrm{CDCl}_{3}\right): \delta 7.65(\mathrm{~d}, \mathrm{~J}=8.2 \mathrm{~Hz}, 1 \mathrm{H}), 7.46$ 
(d, $J=1.7 \mathrm{~Hz}, 1 \mathrm{H}), 7.24(\mathrm{dd}, J=8.3,1.7 \mathrm{~Hz}, 1 \mathrm{H}), 7.22(\mathrm{~s}, 1 \mathrm{H}), 6.88(\mathrm{~s}, 1 \mathrm{H}), 4.23-4.04(\mathrm{~m}, 2 \mathrm{H})$, $3.96(\mathrm{~s}, 3 \mathrm{H})$. LC-MS $(\mathrm{m} / \mathrm{z})=248[\mathrm{M}+\mathrm{H}]^{+}$.

\section{N-(7-chloro-2-methoxydibenzo[b,d]furan-3-yl)-5-oxo-1-tosylpyrrolidine-2-carboxamide}

(27). To a solution of $27 \mathrm{f} \mathrm{(45} \mathrm{mg,} 0.182 \mathrm{mmol}, 1.0 \mathrm{eq})$ and 5-oxo-1-tosylpyrrolidine-2-carboxylic acid ( $62 \mathrm{mg}, 0.218 \mathrm{mmol}, 1.2 \mathrm{eq}$ ) in pyridine $\left(2.0 \mathrm{~mL}\right.$ ), $\mathrm{POCl}_{3}(20 \mathrm{drops})$ was added. The mixture was stirred at $65{ }^{\circ} \mathrm{C}$ for $4 \mathrm{~h}$. $5 \%$ citric acid was added, and the mixture was extracted with EA. The organic phase was washed with water, brine, and dried over $\mathrm{Na}_{2} \mathrm{SO}_{4}$. It was filtered and concentrated. The residue was purified with prep-TLC to give the desired product (15 mg). ${ }^{1} \mathrm{H}$ $\operatorname{NMR}\left(400 \mathrm{MHz}, \mathrm{CDCl}_{3}\right): \delta 8.66(\mathrm{~s}, 1 \mathrm{H}), 8.56(\mathrm{~s}, 1 \mathrm{H}), 7.94(\mathrm{~d}, J=8.3 \mathrm{~Hz}, 2 \mathrm{H}), 7.77$ (d, J = 8.3 Hz, $1 \mathrm{H}), 7.57(\mathrm{~d}, J=1.6 \mathrm{~Hz}, 1 \mathrm{H}), 7.37(\mathrm{~d}, J=3.7 \mathrm{~Hz}, 1 \mathrm{H}), 7.31(\mathrm{dd}, J=12.0,5.2 \mathrm{~Hz}, 3 \mathrm{H}), 4.94(\mathrm{dd}, J$ $=8.3,2.0 \mathrm{~Hz}, 1 \mathrm{H}), 4.04(\mathrm{~s}, 3 \mathrm{H}), 2.80(\mathrm{~m}, 1 \mathrm{H}), 2.51-2.30(\mathrm{~m}, 6 \mathrm{H}) . \mathrm{LC}-\mathrm{MS}(\mathrm{m} / \mathrm{z})=513[\mathrm{M}+\mathrm{H}]^{+}$. 


\section{FIGURE LEGENDS}

Figure 1. Identification of druggable targets implicated in glioblastoma multiforme (GBM). (a) Workflow used to identify GBM-specific druggable targets through integration of genomic RNA-seq, somatic mutation, protein-protein interaction network, and protein structure data. Small-molecule compounds were screened against these pockets to identify compounds that could target proteins implicated in GBM. (b) Differential expression analysis of 169 tumor and 5 normal GBM RNA-seq samples from TCGA. Mean fitted counts for each gene are shown on the $x$ - and y-axis, respectively. (c) Protein-protein interaction subnetwork of GBM-specific targets. Proteins are shown as squares if there is a solved human crystal structure available or as circles otherwise. Proteins with a druggable binding pocket on an associated structure are colored red or white otherwise. (d) Degree (number of edges) versus betweenness centrality for GBM-specific targets from (c). (e) Waterfall plot of each compound's number of predicted GBM-specific targets using an SVR-KB cutoff of $10 \mathrm{nM}$. (f) Histogram plot showing the percentage of compounds predicted to bind to the number of GBM-specific targets using an SVR-KB cutoff of $10 \mathrm{nM}$.

Figure 2. Screening compounds against GBM43 leads to the identification of 1 (IPR-2025). (a) Compounds that were predicted to bind GBM-specific proteins were screened at a concentration of $25 \mu \mathrm{M}$ with $0.5 \%$ DMSO for their effect on cell viability of GBM43 spheroids (mean \pm s.d.; $n=3$ ). Culture medium, culture medium with $1 \%$ DMSO, a TGV cocktail (200 $\mu \mathrm{M}$ temozolomide, $12.5 \mu \mathrm{M}$ ipatasertib/GDC-0068 [pan AKT inhibitor], 12.5 $\mu \mathrm{M}$ voxtalisib/VOX [PI3K/mTOR inhibitor]), CCNU (50 $\mu \mathrm{M}$ lomustine) are also shown. (b) Structure of 1, which emerged from screening top candidates. (c) Stability of 1 in buffer (0.5 mL of a $1 \mathrm{~mL}$ incubation) using high performance liquid chromatography (HPLC). (d) Concentration-dependent study of 1 in glioblastoma multiforme (GBM), normal, and pancreatic adenocarcinoma (PDAC) cell lines (mean \pm s.d.; $n=3$ ). (e) $I C_{50}$ values from fitting concentration-dependent curves from (d). NI corresponds to no inhibition. (f) Concentration-dependent study of CCNU (lomustine) in GBM43 and GBM10 spheroids. (g) Tube formation of brain microvascular endothelial cells treated with 1 compared to DMSO control. (h) Concentration-dependent angiogenesis assay evaluating tube formation of 1 . Compound 1 has an approximate $\mathrm{IC}_{50}$ of $0.1 \mu \mathrm{M}$.

Figure 3. Compound activities of resynthesized 1 (IPR-2025) and synthesized derivatives. Compound activity of 1 and six synthesized derivatives in the three GBM cell lines GBM43, 
GBM10, and SJ-GBM2. The molecular structures, calculated physicochemical properties, and $\mathrm{GBM} I \mathrm{IC}_{50} \mathrm{~S}$ are provided in the table to the right. $\mathrm{NI}$ and ND denote 'No Inhibition' and 'Not determined', respectively.

Figure 4. RNA-Seq of 1 (IPR-2025) treated GBM43 cells. (a) Volcano plot of fold change versus log-transformed significance of GBM43 cells treated with $10 \mu \mathrm{M}$ of 1 versus control. Differentially expressed genes are identified using a $\log _{2}$ fold change cutoff of 1 . (b) The top 15 most overexpressed and underexpressed genes identified in cells treated with GBM43. (c) The most similar 30 perturbagens to the gene signature of treated GBM43 identified using the L1000 platform. Perturbagens are rank-ordered using the median T statistic across nine cell lines, and are classified into gene knockdown (KD), overexpression (OE), and compounds (CP).

Figure 5. Thermal proteome profiling of 1 (IPR-2025) treated GBM43 Cells. (a) GBM43 cells treated with $10 \mu \mathrm{M} 1$ and untreated cells were serially heated to six different temperatures for thermal proteome profiling. Proteins were identified and quantified using mass spectrometry. Melting curves were fitted for each protein to determine the shift in melting temperature between untreated and treated proteins $\left(\Delta \mathrm{T}_{\mathrm{m}}\right)$. The panel shows a scatterplot of the calculated melting temperature $\left(T_{m}\right)$ in individual proteins between vehicle and compound-treated experiments. (b) The list of proteins found to have the largest increase in melting temperature when treated with $1\left(\Delta T_{m} \geq 3^{\circ} \mathrm{C}\right)$. (c) The list of proteins found to have the largest decrease in melting temperature when treated with $1\left(\Delta \mathrm{T}_{\mathrm{m}} \leq-3^{\circ} \mathrm{C}\right)$. (d) Comparison of proteins implicated by 1 . The SVR-KB predicted targets (orange), differentially expressed genes (overexpressed: yellow, underexpressed: blue-purple), most similar perturbagens from L1000 analysis of differentially expressed RNA-seq genes (KD: purple, OE: blue), and proteins from thermal proteome profiling $\left(\Delta T_{m} \geq 3{ }^{\circ} \mathrm{C}\right.$ : green, $\Delta \mathrm{T}_{\mathrm{m}} \leq-3^{\circ} \mathrm{C}$ : red) are represented as nodes. Node borders are black if there is a solved human crystal structure available or uncolored otherwise. Nodes appear as rectangles if there is a druggable binding pocket on the associated protein or circles otherwise. Connections between nodes are built using STRING. Edges between connected proteins are filtered by confidence (STRING confidence: high, score $\geq 0.7$ ) and colored based on the source of evidence (co-expression: black, database: blue, experimental: magenta). Unconnected nodes are omitted. 


\section{SUPPORTING INFORMATION}

The supporting information is available free of charge at http://pubs.acs.org: Protein targets and compounds identified from integrative analysis, compound structures and physicochemical properties, concentration-dependent curves against GBM spheroids, cell viability studies, thermal proteome profiling curves, and possible mechanism for reaction of 1.

- Supporting data (supplementary figures and tables) (PDF)

- Table S1. GBM protein targets identified from analysis of TCGA genomic and mutation, PPI network, and PDB structural data (XLSX)

- Table S2. Compounds identified from virtual screening against TCGA GBM (XLSX) 


\section{ACKNOWLEDGEMENTS}

Research was supported by the Research Support Grant Fund (SOM), American Cancer Society Research Scholar Grant (SOM), Biomedical Research Grant (SOM), and National Cancer Institute R01 CA138798 (KEP). Computer time on the Karst and Carbonate supercomputers at Indiana University is supported in part by Lilly Endowment, Inc., through its support for the Indiana University Pervasive Technology Institute, and in part by the Indiana METACyt Initiative. This research was done using resources provided by the Open Science Grid, which is supported by the National Science Foundation award 1148698, and the U.S. Department of Energy's Office of Science. 
Table 1. Predicted protein targets of 1 (IPR-2025)

\begin{tabular}{|c|c|c|c|c|c|c|}
\hline \multirow[b]{2}{*}{ Symbol } & \multirow[b]{2}{*}{ Name } & \multirow[b]{2}{*}{$\begin{array}{l}\text { Protein } \\
\text { Family }\end{array}$} & \multicolumn{2}{|c|}{ PPI Network } & \multicolumn{2}{|c|}{ TCGA GBM } \\
\hline & & & Degree & $\begin{array}{c}\text { Betweenness } \\
\text { Centrality }\end{array}$ & $\begin{array}{c}\text { Fold } \\
\text { Change }\end{array}$ & Mutations \\
\hline \multicolumn{7}{|c|}{ Protein-Protein Interaction Interface } \\
\hline PLK1 & Serine/threonine-protein kinase PLK1 & Ser/Thr protein kinase & 15 & $1.70 \mathrm{E}-03$ & 3.3 & 9 \\
\hline NCF1 & Neutrophil cytosol factor 1 & - & 9 & $1.70 \mathrm{E}-04$ & 2.3 & 6 \\
\hline PNP & Purine nucleoside phosphorylase & PNP/MTAP phosphorylase & 2 & $0.00 \mathrm{E}+00$ & 1.4 & 6 \\
\hline \multicolumn{7}{|c|}{ DNA-Binding Site } \\
\hline EXO1 & Exonuclease 1 & XPG/RAD2 endonuclease & 10 & $3.40 \mathrm{E}-04$ & 3.7 & 14 \\
\hline TOP2A & DNA topoisomerase 2-alpha & Type II topoisomerase & 3 & $2.50 \mathrm{E}-05$ & 7.2 & 10 \\
\hline \multicolumn{7}{|c|}{ Beta-Propeller } \\
\hline CDC20 & Cell division cycle protein 20 homolog & WD repeat CDC20/Fizzy & 8 & $3.10 \mathrm{E}-04$ & 3.5 & 9 \\
\hline GNB1 & Guanine nucleotide-binding protein $G(I) / G(S) / G(T)$ subunit beta-1 & WD repeat $\mathrm{G}$ protein beta & 29 & $4.60 \mathrm{E}-03$ & 2.0 & 9 \\
\hline ITGA5 & Integrin alpha-5 & Integrin alpha chain & 2 & $1.50 \mathrm{E}-05$ & 3.0 & 11 \\
\hline RACK1 & Receptor of activated protein $\mathrm{C}$ kinase 1 & WD repeat $G$ protein beta & 5 & 1.10E-04 & 1.4 & 6 \\
\hline \multicolumn{7}{|c|}{ Allosteric Site near Protein-Protein Interaction Interface } \\
\hline NCF2 & Neutrophil cytosol factor 2 & NCF2/NOXA1 & 8 & $6.50 \mathrm{E}-04$ & 2.3 & 9 \\
\hline NEDD4 & E3 ubiquitin-protein ligase NEDD4 & - & 15 & $1.10 \mathrm{E}-03$ & 2.0 & 15 \\
\hline PYGL & Glycogen phosphorylase, liver form & Glycogen phosphorylase & 3 & $0.00 \mathrm{E}+00$ & 3.2 & 19 \\
\hline \multicolumn{7}{|c|}{ Allosteric Site near Enzymatic Nucleoside } \\
\hline KIF11 & Kinesin-like protein KIF11 & Kinesin & 4 & $8.40 \mathrm{E}-06$ & 2.8 & 6 \\
\hline TAP1 & Antigen peptide transporter 1 & $A B C$ transporter & 2 & $2.40 \mathrm{E}-04$ & 2.4 & 12 \\
\hline \multicolumn{7}{|c|}{ Other Allosteric Site } \\
\hline ACE & Angiotensin-converting enzyme & Peptidase M2 & 1 & $0.00 \mathrm{E}+00$ & 1.9 & 19 \\
\hline CENPE & Centromere-associated protein $\mathrm{E}$ & Kinesin & 6 & $7.50 \mathrm{E}-05$ & 2.8 & 17 \\
\hline $\mathrm{EZH} 2$ & Histone-lysine N-methyltransferase EZH2 & Histone-lysine methyltransferase & 6 & $2.00 \mathrm{E}-04$ & 4.5 & 10 \\
\hline FLNA & Filamin-A & Filamin & 34 & $7.90 \mathrm{E}-03$ & 2.5 & 20 \\
\hline GUSB & Beta-glucuronidase & Glycosyl hydrolase & 2 & $0.00 \mathrm{E}+00$ & 2.0 & 7 \\
\hline MMP2 & $72 \mathrm{kDa}$ type IV collagenase & Peptidase M10A & 4 & $7.40 \mathrm{E}-04$ & 3.9 & 12 \\
\hline MMP9 & Matrix metalloproteinase- 9 & Peptidase M10A & 4 & $1.60 \mathrm{E}-08$ & 7.3 & 8 \\
\hline NR5A2 & Nuclear receptor subfamily 5 group A member 2 & Nuclear hormone receptor & 6 & $3.10 \mathrm{E}-05$ & 4.4 & 6 \\
\hline NRP1 & Neuropilin-1 & Neuropilin & 2 & $4.10 \mathrm{E}-07$ & 1.8 & 18 \\
\hline PLA2G4A & Cytosolic phospholipase A2 & - & 1 & $0.00 \mathrm{E}+00$ & 1.6 & 7 \\
\hline SHMT2 & Serine hydroxymethyltransferase, mitochondrial & SHMT & 2 & $3.60 \mathrm{E}-06$ & 2.0 & 7 \\
\hline SPARC & SPARC & SPARC & 1 & $0.00 \mathrm{E}+00$ & 3.1 & 7 \\
\hline TLR2 & Toll-like receptor 2 & Toll-like receptor & 3 & $4.40 \mathrm{E}-05$ & 2.0 & 17 \\
\hline
\end{tabular}




\section{REFERENCES}

1. Hanahan, D., and Weinberg, R. A. (2000) The Hallmarks of Cancer. Cell 100, 57-70

2. Weinstein, J. N., Collisson, E. A., Mills, G. B., Shaw, K. R. M., Ozenberger, B. A., Ellrott, K., Shmulevich, I., Sander, C., Stuart, J. M., and The Cancer Genome Atlas Research Network. (2013) The Cancer Genome Atlas Pan-Cancer Analysis Project. Nat. Genet. 45, 1113-1120

3. The Cancer Genome Atlas Research Network. (2011) Integrated Genomic Analyses of Ovarian Carcinoma. Nature 474, 609-615

4. The Cancer Genome Atlas Network. (2012) Comprehensive Molecular Characterization of Human Colon and Rectal Cancer. Nature 487, 330-337

5. The Cancer Genome Atlas Network. (2012) Comprehensive Molecular Portraits of Human Breast Tumours. Nature 490, 61-70

6. The Cancer Genome Atlas Research Network. (2013) Comprehensive Molecular Characterization of Clear Cell Renal Cell Carcinoma. Nature 499, 43-49

7. The Cancer Genome Atlas Research Network. (2012) Comprehensive Genomic Characterization of Squamous Cell Lung Cancers. Nature 489, 519-525

8. Weir, B. A., Woo, M. S., Getz, G., Perner, S., Ding, L., Beroukhim, R., Lin, W. M., Province, M. A., Kraja, A., Johnson, L. A., Shah, K., Sato, M., Thomas, R. K., Barletta, J. A., Borecki, I. B., Broderick, S., Chang, A. C., Chiang, D. Y., Chirieac, L. R., Cho, J., Fujii, Y., Gazdar, A. F., Giordano, T., Greulich, H., Hanna, M., Johnson, B. E., Kris, M. G., Lash, A., Lin, L., Lindeman, N., Mardis, E. R., McPherson, J. D., Minna, J. D., Morgan, M. B., Nadel, M., Orringer, M. B., Osborne, J. R., Ozenberger, B., Ramos, A. H., Robinson, J., Roth, J. A., Rusch, V., Sasaki, H., Shepherd, F., Sougnez, C., Spitz, M. R., Tsao, M. S., Twomey, D., Verhaak, R. G., Weinstock, G. M., Wheeler, D. A., Winckler, W., Yoshizawa, A., Yu, S., Zakowski, M. F., Zhang, Q., Beer, D. G., Wistuba, II, Watson, M. A., Garraway, L. A., Ladanyi, M., Travis, W. D., Pao, W., Rubin, M. A., Gabriel, S. B., Gibbs, R. A., Varmus, H. E., Wilson, R. K., Lander, E. S., and Meyerson, M. (2007) Characterizing the Cancer Genome in Lung Adenocarcinoma. Nature 450, 893-898

9. The Cancer Genome Atlas Research Network. (2014) Comprehensive Molecular Profiling of Lung Adenocarcinoma. Nature 511, 543-550

10. Bailey, P., Chang, D. K., Nones, K., Johns, A. L., Patch, A. M., Gingras, M. C., Miller, D. K., Christ, A. N., Bruxner, T. J., Quinn, M. C., Nourse, C., Murtaugh, L. C., Harliwong, I., Idrisoglu, S., Manning, S., Nourbakhsh, E., Wani, S., Fink, L., Holmes, O., Chin, V., Anderson, M. J., Kazakoff, S., Leonard, C., Newell, F., Waddell, N., Wood, S., Xu, Q., Wilson, P. J., Cloonan, N., Kassahn, K. S., Taylor, D., Quek, K., Robertson, A., Pantano, L., Mincarelli, L., Sanchez, L. N., Evers, L., Wu, J., Pinese, M., Cowley, M. J., Jones, M. D., Colvin, E. K., Nagrial, A. M., Humphrey, E. S., Chantrill, L. A., Mawson, A., Humphris, J., Chou, A., Pajic, M., Scarlett, C. J., Pinho, A. V., Giry-Laterriere, M., Rooman, I., Samra, J. S., Kench, J. G., Lovell, J. A., Merrett, N. D., Toon, C. W., Epari, K., Nguyen, N. Q., Barbour, A., Zeps, N., Moran-Jones, K., Jamieson, N. B., Graham, J. S., Duthie, F., Oien, K., Hair, J., Grutzmann, R., Maitra, A., lacobuzio-Donahue, C. A., Wolfgang, C. L., Morgan, R. A., Lawlor, R. T., Corbo, V., Bassi, C., Rusev, B., Capelli, P., Salvia, R., Tortora, G., Mukhopadhyay, D., Petersen, G. M., Australian Pancreatic Cancer Genome, I., Munzy, D. M., Fisher, W. E., Karim, S. A., Eshleman, J. R., Hruban, R. H., Pilarsky, C., Morton, J. P., Sansom, O. J., Scarpa, A., Musgrove, E. A., Bailey, U. M., Hofmann, O., Sutherland, R. L., Wheeler, D. A., Gill, A. J., Gibbs, R. A., Pearson, J. V., Waddell, N., Biankin, A. V., and Grimmond, S. M. (2016) Genomic Analyses Identify Molecular Subtypes of Pancreatic Cancer. Nature 531, 47-52

11. Biankin, A. V., Waddell, N., Kassahn, K. S., Gingras, M. C., Muthuswamy, L. B., Johns, A. L., Miller, D. K., Wilson, P. J., Patch, A. M., Wu, J., Chang, D. K., Cowley, M. J., Gardiner, 
B. B., Song, S., Harliwong, I., Idrisoglu, S., Nourse, C., Nourbakhsh, E., Manning, S., Wani, S., Gongora, M., Pajic, M., Scarlett, C. J., Gill, A. J., Pinho, A. V., Rooman, I., Anderson, M., Holmes, O., Leonard, C., Taylor, D., Wood, S., Xu, Q., Nones, K., Fink, J. L., Christ, A., Bruxner, T., Cloonan, N., Kolle, G., Newell, F., Pinese, M., Mead, R. S., Humphris, J. L., Kaplan, W., Jones, M. D., Colvin, E. K., Nagrial, A. M., Humphrey, E. S., Chou, A., Chin, V. T., Chantrill, L. A., Mawson, A., Samra, J. S., Kench, J. G., Lovell, J. A., Daly, R. J., Merrett, N. D., Toon, C., Epari, K., Nguyen, N. Q., Barbour, A., Zeps, N., Australian Pancreatic Cancer Genome, I., Kakkar, N., Zhao, F., Wu, Y. Q., Wang, M., Muzny, D. M., Fisher, W. E., Brunicardi, F. C., Hodges, S. E., Reid, J. G., Drummond, J., Chang, K., Han, Y., Lewis, L. R., Dinh, H., Buhay, C. J., Beck, T., Timms, L., Sam, M., Begley, K., Brown, A., Pai, D., Panchal, A., Buchner, N., De Borja, R., Denroche, R. E., Yung, C. K., Serra, S., Onetto, N., Mukhopadhyay, D., Tsao, M. S., Shaw, P. A., Petersen, G. M., Gallinger, S., Hruban, R. H., Maitra, A., lacobuzio-Donahue, C. A., Schulick, R. D., Wolfgang, C. L., Morgan, R. A., Lawlor, R. T., Capelli, P., Corbo, V., Scardoni, M., Tortora, G., Tempero, M. A., Mann, K. M., Jenkins, N. A., Perez-Mancera, P. A., Adams, D. J., Largaespada, D. A., Wessels, L. F., Rust, A. G., Stein, L. D., Tuveson, D. A., Copeland, N. G., Musgrove, E. A., Scarpa, A., Eshleman, J. R., Hudson, T. J., Sutherland, R. L., Wheeler, D. A., Pearson, J. V., McPherson, J. D., Gibbs, R. A., and Grimmond, S. M. (2012) Pancreatic Cancer Genomes Reveal Aberrations in Axon Guidance Pathway Genes. Nature 491, 399-405

12. Brennan, C. W., Verhaak, R. G., McKenna, A., Campos, B., Noushmehr, H., Salama, S. R., Zheng, S., Chakravarty, D., Sanborn, J. Z., Berman, S. H., Beroukhim, R., Bernard, B., Wu, C. J., Genovese, G., Shmulevich, I., Barnholtz-Sloan, J., Zou, L., Vegesna, R., Shukla, S. A., Ciriello, G., Yung, W. K., Zhang, W., Sougnez, C., Mikkelsen, T., Aldape, K., Bigner, D. D., Van Meir, E. G., Prados, M., Sloan, A., Black, K. L., Eschbacher, J., Finocchiaro, G., Friedman, W., Andrews, D. W., Guha, A., lacocca, M., O'Neill, B. P., Foltz, G., Myers, J., Weisenberger, D. J., Penny, R., Kucherlapati, R., Perou, C. M., Hayes, D. N., Gibbs, R., Marra, M., Mills, G. B., Lander, E., Spellman, P., Wilson, R., Sander, C., Weinstein, J., Meyerson, M., Gabriel, S., Laird, P. W., Haussler, D., Getz, G., Chin, L., and The Cancer Genome Atlas Research Network. (2013) The Somatic Genomic Landscape of Glioblastoma. Cell 155, 462-477

13. Parsons, D. W., Jones, S., Zhang, X., Lin, J. C., Leary, R. J., Angenendt, P., Mankoo, P., Carter, H., Siu, I. M., Gallia, G. L., Olivi, A., McLendon, R., Rasheed, B. A., Keir, S., Nikolskaya, T., Nikolsky, Y., Busam, D. A., Tekleab, H., Diaz, L. A., Jr., Hartigan, J., Smith, D. R., Strausberg, R. L., Marie, S. K., Shinjo, S. M., Yan, H., Riggins, G. J., Bigner, D. D., Karchin, R., Papadopoulos, N., Parmigiani, G., Vogelstein, B., Velculescu, V. E., and Kinzler, K. W. (2008) An Integrated Genomic Analysis of Human Glioblastoma Multiforme. Science 321, 1807-1812

14. Reddy, A. S., and Zhang, S. (2013) Polypharmacology: Drug Discovery for the Future. Expert Rev. Clin. Pharmacol. 6, 41-47

15. Viollet, B., Guigas, B., Sanz Garcia, N., Leclerc, J., Foretz, M., and Andreelli, F. (2012) Cellular and Molecular Mechanisms of Metformin: An Overview. Clin. Sci. 122, 253-270

16. Vane, J. R., and Botting, R. M. (2003) The Mechanism of Action of Aspirin. Thromb. Res. 110, 255-258

17. Moffat, J. G., Rudolph, J., and Bailey, D. (2014) Phenotypic Screening in Cancer Drug Discovery - Past, Present and Future. Nat. Rev. Drug Discovery 13, 588-602

18. Swinney, D. C., and Anthony, J. (2011) How Were New Medicines Discovered? Nat. Rev. Drug Discovery 10, 507-519

19. Batash, R., Asna, N., Schaffer, P., Francis, N., and Schaffer, M. (2017) Glioblastoma Multiforme, Diagnosis and Treatment; Recent Literature Review. Curr. Med. Chem. 24, 3002-3009 
20. Stupp, R., Mason, W. P., van den Bent, M. J., Weller, M., Fisher, B., Taphoorn, M. J., Belanger, K., Brandes, A. A., Marosi, C., Bogdahn, U., Curschmann, J., Janzer, R. C., Ludwin, S. K., Gorlia, T., Allgeier, A., Lacombe, D., Cairncross, J. G., Eisenhauer, E., Mirimanoff, R. O., European Organisation for, R., Treatment of Cancer Brain, T., Radiotherapy, G., and National Cancer Institute of Canada Clinical Trials, G. (2005) Radiotherapy Plus Concomitant and Adjuvant Temozolomide for Glioblastoma. N. Engl. J. Med. 352, 987-996

21. deCarvalho, A. C., Kim, H., Poisson, L. M., Winn, M. E., Mueller, C., Cherba, D., Koeman, J., Seth, S., Protopopov, A., Felicella, M., Zheng, S., Multani, A., Jiang, Y., Zhang, J., Nam, D. H., Petricoin, E. F., Chin, L., Mikkelsen, T., and Verhaak, R. G. W. (2018) Discordant Inheritance of Chromosomal and Extrachromosomal DNA Elements Contributes to Dynamic Disease Evolution in Glioblastoma. Nat. Genet. 50, 708-717

22. Sottoriva, A., Spiteri, I., Piccirillo, S. G., Touloumis, A., Collins, V. P., Marioni, J. C., Curtis, C., Watts, C., and Tavare, S. (2013) Intratumor Heterogeneity in Human Glioblastoma Reflects Cancer Evolutionary Dynamics. Proc. Natl. Acad. Sci. U. S. A. 110, 4009-4014

23. Finocchiaro, G., and Pellegatta, S. (2014) Perspectives for Immunotherapy in Glioblastoma Treatment. Curr. Opin. Oncol. 26, 608-614

24. Mangani, D., Weller, M., and Roth, P. (2017) The Network of Immunosuppressive Pathways in Glioblastoma. Biochem. Pharmacol. 130, 1-9

25. Nduom, E. K., Weller, M., and Heimberger, A. B. (2015) Immunosuppressive Mechanisms in Glioblastoma. Neuro-Oncology 17 Suppl 7, vii9-vii14

26. Banissi, C., Ghiringhelli, F., Chen, L., and Carpentier, A. F. (2009) Treg Depletion with a Low-Dose Metronomic Temozolomide Regimen in a Rat Glioma Model. Cancer Immunol. Immunother. 58, 1627-1634

27. Karachi, A., Dastmalchi, F., Mitchell, D., and Rahman, M. (2018) Temozolomide for Immunomodulation in the Treatment of Glioblastoma. Neuro-Oncology 20, 1566-1572

28. Litterman, A. J., Zellmer, D. M., Grinnen, K. L., Hunt, M. A., Dudek, A. Z., Salazar, A. M., and Ohlfest, J. R. (2013) Profound Impairment of Adaptive Immune Responses by Alkylating Chemotherapy. J. Immunol. 190, 6259-6268

29. Wu, J., and Waxman, D. J. (2015) Metronomic Cyclophosphamide Eradicates Large Implanted GL261 Gliomas by Activating Antitumor Cd8(+) T-Cell Responses and Immune Memory. Oncolmmunology 4, e1005521

30. Jones, L. H., and Bunnage, M. E. (2017) Applications of Chemogenomic Library Screening in Drug Discovery. Nat. Rev. Drug Discovery 16, 285-296

31. Wang, Y., Cornett, A., King, F. J., Mao, Y., Nigsch, F., Paris, C. G., McAllister, G., and Jenkins, J. L. (2016) Evidence-Based and Quantitative Prioritization of Tool Compounds in Phenotypic Drug Discovery. Cell Chem. Biol. 23, 862-874

32. Arrowsmith, C. H., Audia, J. E., Austin, C., Baell, J., Bennett, J., Blagg, J., Bountra, C., Brennan, P. E., Brown, P. J., Bunnage, M. E., Buser-Doepner, C., Campbell, R. M., Carter, A. J., Cohen, P., Copeland, R. A., Cravatt, B., Dahlin, J. L., Dhanak, D., Edwards, A. M., Frederiksen, M., Frye, S. V., Gray, N., Grimshaw, C. E., Hepworth, D., Howe, T., Huber, K. V., Jin, J., Knapp, S., Kotz, J. D., Kruger, R. G., Lowe, D., Mader, M. M., Marsden, B., Mueller-Fahrnow, A., Muller, S., O'Hagan, R. C., Overington, J. P., Owen, D. R., Rosenberg, S. H., Roth, B., Ross, R., Schapira, M., Schreiber, S. L., Shoichet, B., Sundstrom, M., Superti-Furga, G., Taunton, J., Toledo-Sherman, L., Walpole, C., Walters, M. A., Willson, T. M., Workman, P., Young, R. N., and Zuercher, W. J. (2015) The Promise and Peril of Chemical Probes. Nat. Chem. Biol. 11, 536-541

33. Finan, C., Gaulton, A., Kruger, F. A., Lumbers, R. T., Shah, T., Engmann, J., Galver, L., Kelley, R., Karlsson, A., Santos, R., Overington, J. P., Hingorani, A. D., and Casas, J. P. (2017) The Druggable Genome and Support for Target Identification and Validation in Drug Development. Sci. Transl. Med. 9, eaag1166 
34. Santos, R., Ursu, O., Gaulton, A., Bento, A. P., Donadi, R. S., Bologa, C. G., Karlsson, A., Al-Lazikani, B., Hersey, A., Oprea, T. I., and Overington, J. P. (2017) A Comprehensive Map of Molecular Drug Targets. Nat. Rev. Drug Discovery 16, 19-34

35. Sterling, T., and Irwin, J. J. (2015) ZINC 15--Ligand Discovery for Everyone. J. Chem. Inf. Model. 55, 2324-2337

36. Irwin, J. J., Gaskins, G., Sterling, T., Mysinger, M. M., and Keiser, M. J. (2018) Predicted Biological Activity of Purchasable Chemical Space. J. Chem. Inf. Model. 58, 148-164

37. Wawer, M. J., Li, K., Gustafsdottir, S. M., Ljosa, V., Bodycombe, N. E., Marton, M. A., Sokolnicki, K. L., Bray, M. A., Kemp, M. M., Winchester, E., Taylor, B., Grant, G. B., Hon, C. S., Duvall, J. R., Wilson, J. A., Bittker, J. A., Dancik, V., Narayan, R., Subramanian, A., Winckler, W., Golub, T. R., Carpenter, A. E., Shamji, A. F., Schreiber, S. L., and Clemons, P. A. (2014) Toward Performance-Diverse Small-Molecule Libraries for Cell-Based Phenotypic Screening Using Multiplexed High-Dimensional Profiling. Proc. Natl. Acad. Sci. U. S. A. 111, 10911-10916

38. Chevillard, F., and Kolb, P. (2015) SCUBIDOO: A Large yet Screenable and Easily Searchable Database of Computationally Created Chemical Compounds Optimized toward High Likelihood of Synthetic Tractability. J. Chem. Inf. Model. 55, 1824-1835

39. Edmondson, R., Broglie, J. J., Adcock, A. F., and Yang, L. (2014) Three-Dimensional Cell Culture Systems and Their Applications in Drug Discovery and Cell-Based Biosensors. Assay Drug Dev. Technol. 12, 207-218

40. Duval, K., Grover, H., Han, L. H., Mou, Y., Pegoraro, A. F., Fredberg, J., and Chen, Z. (2017) Modeling Physiological Events in 2D vs. 3D Cell Culture. Physiology 32, 266-277

41. Dasari, S., and Tchounwou, P. B. (2014) Cisplatin in Cancer Therapy: Molecular Mechanisms of Action. Eur. J. Pharmacol. 740, 364-378

42. Mitra, A., Mishra, L., and Li, S. (2013) Technologies for Deriving Primary Tumor Cells for Use in Personalized Cancer Therapy. Trends Biotechnol. 31, 347-354

43. Maeda, H., and Khatami, M. (2018) Analyses of Repeated Failures in Cancer Therapy for Solid Tumors: Poor Tumor-Selective Drug Delivery, Low Therapeutic Efficacy and Unsustainable Costs. Clin. Transl. Med. 7, 11

44. Berman, H. M., Westbrook, J., Feng, Z., Gilliland, G., Bhat, T. N., Weissig, H., Shindyalov, I. N., and Bourne, P. E. (2000) The Protein Data Bank. Nucleic Acids Res. 28, 235-242

45. Xu, D., Jalal, S. I., Sledge, G. W., and Meroueh, S. O. (2016) Small-Molecule Binding Sites to Explore Protein-Protein Interactions in the Cancer Proteome. Mol. BioSyst. 12, 3067-3087

46. Rolland, T., Tasan, M., Charloteaux, B., Pevzner, S. J., Zhong, Q., Sahni, N., Yi, S., Lemmens, I., Fontanillo, C., Mosca, R., Kamburov, A., Ghiassian, S. D., Yang, X., Ghamsari, L., Balcha, D., Begg, B. E., Braun, P., Brehme, M., Broly, M. P., Carvunis, A. R., Convery-Zupan, D., Corominas, R., Coulombe-Huntington, J., Dann, E., Dreze, M., Dricot, A., Fan, C., Franzosa, E., Gebreab, F., Gutierrez, B. J., Hardy, M. F., Jin, M., Kang, S., Kiros, R., Lin, G. N., Luck, K., MacWilliams, A., Menche, J., Murray, R. R., Palagi, A., Poulin, M. M., Rambout, X., Rasla, J., Reichert, P., Romero, V., Ruyssinck, E., Sahalie, J. M., Scholz, A., Shah, A. A., Sharma, A., Shen, Y., Spirohn, K., Tam, S., Tejeda, A. O., Trigg, S. A., Twizere, J. C., Vega, K., Walsh, J., Cusick, M. E., Xia, Y., Barabasi, A. L., lakoucheva, L. M., Aloy, P., De Las Rivas, J., Tavernier, J., Calderwood, M. A., Hill, D. E., Hao, T., Roth, F. P., and Vidal, M. (2014) A Proteome-Scale Map of the Human Interactome Network. Cell 159, 1212-1226

47. Li, L., Wang, B., and Meroueh, S. O. (2011) Support Vector Regression Scoring of Receptor-Ligand Complexes for Rank-Ordering and Virtual Screening of Chemical Libraries. J. Chem. Inf. Model. 51, 2132-2138

48. Wang, H., Cai, S., Bailey, B. J., Reza Saadatzadeh, M., Ding, J., Tonsing-Carter, E., Georgiadis, T. M., Zachary Gunter, T., Long, E. C., Minto, R. E., Gordon, K. R., Sen, S. 
E., Cai, W., Eitel, J. A., Waning, D. L., Bringman, L. R., Wells, C. D., Murray, M. E., Sarkaria, J. N., Gelbert, L. M., Jones, D. R., Cohen-Gadol, A. A., Mayo, L. D., Shannon, H. E., and Pollok, K. E. (2017) Combination Therapy in a Xenograft Model of Glioblastoma: Enhancement of the Antitumor Activity of Temozolomide by an MDM2 Antagonist. J. Neurosurg. 126, 446-459

49. Herrera-Perez, R. M., Voytik-Harbin, S. L., Sarkaria, J. N., Pollok, K. E., Fishel, M. L., and Rickus, J. L. (2018) Presence of Stromal Cells in a Bioengineered Tumor Microenvironment Alters Glioblastoma Migration and Response to STAT3 Inhibition. PLoS One 13, e0194183

50. Sarkaria, J. N., Carlson, B. L., Schroeder, M. A., Grogan, P., Brown, P. D., Giannini, C., Ballman, K. V., Kitange, G. J., Guha, A., Pandita, A., and James, C. D. (2006) Use of an Orthotopic Xenograft Model for Assessing the Effect of Epidermal Growth Factor Receptor Amplification on Glioblastoma Radiation Response. Clin. Cancer Res. 12, 2264-2271

51. Kang, M. H., Smith, M. A., Morton, C. L., Keshelava, N., Houghton, P. J., and Reynolds, C. P. (2011) National Cancer Institute Pediatric Preclinical Testing Program: Model Description for in vitro Cytotoxicity Testing. Pediatr. Blood Cancer 56, 239-249

52. Bum-Erdene, K., Zhou, D., Gonzalez-Gutierrez, G., Ghozayel, M. K., Si, Y., Xu, D., Shannon, H. E., Bailey, B. J., Corson, T. W., Pollok, K. E., Wells, C. D., and Meroueh, S. O. (2019) Small-Molecule Covalent Modification of Conserved Cysteine Leads to Allosteric Inhibition of the TEAD-Yap Protein-Protein Interaction. Cell Chem. Biol. 26, 378389.e313

53. Kitange, G. J., Carlson, B. L., Schroeder, M. A., Grogan, P. T., Lamont, J. D., Decker, P. A., Wu, W., James, C. D., and Sarkaria, J. N. (2009) Induction of MGMT Expression Is Associated With Temozolomide Resistance in Glioblastoma Xenografts. Neuro-Oncology 11, 281-291

54. Cui, Y., Brosnan, J. A., Blackford, A. L., Sur, S., Hruban, R. H., Kinzler, K. W., Vogelstein, B., Maitra, A., Diaz, L. A., Jr., lacobuzio-Donahue, C. A., and Eshleman, J. R. (2012) Genetically Defined Subsets of Human Pancreatic Cancer Show Unique in Vitro Chemosensitivity. Clin. Cancer Res. 18, 6519-6530

55. Jones, S., Zhang, X., Parsons, D. W., Lin, J. C., Leary, R. J., Angenendt, P., Mankoo, P., Carter, H., Kamiyama, H., Jimeno, A., Hong, S. M., Fu, B., Lin, M. T., Calhoun, E. S., Kamiyama, M., Walter, K., Nikolskaya, T., Nikolsky, Y., Hartigan, J., Smith, D. R., Hidalgo, M., Leach, S. D., Klein, A. P., Jaffee, E. M., Goggins, M., Maitra, A., lacobuzio-Donahue, C., Eshleman, J. R., Kern, S. E., Hruban, R. H., Karchin, R., Papadopoulos, N., Parmigiani, G., Vogelstein, B., Velculescu, V. E., and Kinzler, K. W. (2008) Core Signaling Pathways in Human Pancreatic Cancers Revealed by Global Genomic Analyses. Science 321, 1801-1806

56. Arpin, C. C., Mac, S., Jiang, Y., Cheng, H., Grimard, M., Page, B. D., Kamocka, M. M., Haftchenary, S., Su, H., Ball, D. P., Rosa, D. A., Lai, P. S., Gomez-Biagi, R. F., Ali, A. M., Rana, R., Hanenberg, H., Kerman, K., McElyea, K. C., Sandusky, G. E., Gunning, P. T., and Fishel, M. L. (2016) Applying Small Molecule Signal Transducer and Activator of Transcription-3 (STAT3) Protein Inhibitors as Pancreatic Cancer Therapeutics. Mol. Cancer Ther. 15, 794-805

57. Folkman, J. (1971) Tumor Angiogenesis: Therapeutic Implications. N. Engl. J. Med. 285, $1182-1186$

58. Arrillaga-Romany, I., Reardon, D. A., and Wen, P. Y. (2014) Current Status of Antiangiogenic Therapies for Glioblastomas. Expert Opin. Invest. Drugs 23, 199-210

59. Wang, Y., Xing, D., Zhao, M., Wang, J., and Yang, Y. (2016) The Role of a Single Angiogenesis Inhibitor in the Treatment of Recurrent Glioblastoma Multiforme: A MetaAnalysis and Systematic Review. PLoS One 11, e0152170 
60. Plate, K. H., and Mennel, H. D. (1995) Vascular Morphology and Angiogenesis in Glial Tumors. Exp. Toxicol. Pathol. 47, 89-94

61. Schmidt, N. O., Westphal, M., Hagel, C., Ergun, S., Stavrou, D., Rosen, E. M., and Lamszus, K. (1999) Levels of Vascular Endothelial Growth Factor, Hepatocyte Growth Factor/Scatter Factor and Basic Fibroblast Growth Factor in Human Gliomas and Their Relation to Angiogenesis. Int. J. Cancer 84, 10-18

62. Futreal, P. A., Coin, L., Marshall, M., Down, T., Hubbard, T., Wooster, R., Rahman, N., and Stratton, M. R. (2004) A Census of Human Cancer Genes. Nat. Rev. Cancer 4, 177183

63. Wang, Z., Yuan, H., Sun, C., Xu, L., Chen, Y., Zhu, Q., Zhao, H., Huang, Q., Dong, J., and Lan, Q. (2015) GATA2 Promotes Glioma Progression Through EGFR/ERK/Elk-1 Pathway. Med. Oncol. 32, 87

64. D'Alessio, A., Proietti, G., Lama, G., Biamonte, F., Lauriola, L., Moscato, U., Vescovi, A., Mangiola, A., Angelucci, C., and Sica, G. (2016) Analysis of Angiogenesis Related Factors in Glioblastoma, Peritumoral Tissue and Their Derived Cancer Stem Cells. Oncotarget 7, 78541-78556

65. Lamb, J., Crawford, E. D., Peck, D., Modell, J. W., Blat, I. C., Wrobel, M. J., Lerner, J., Brunet, J. P., Subramanian, A., Ross, K. N., Reich, M., Hieronymus, H., Wei, G., Armstrong, S. A., Haggarty, S. J., Clemons, P. A., Wei, R., Carr, S. A., Lander, E. S., and Golub, T. R. (2006) The Connectivity Map: Using Gene-Expression Signatures to Connect Small Molecules, Genes, and Disease. Science 313, 1929-1935

66. Subramanian, A., Narayan, R., Corsello, S. M., Peck, D. D., Natoli, T. E., Lu, X., Gould, J., Davis, J. F., Tubelli, A. A., Asiedu, J. K., Lahr, D. L., Hirschman, J. E., Liu, Z., Donahue, M., Julian, B., Khan, M., Wadden, D., Smith, I. C., Lam, D., Liberzon, A., Toder, C., Bagul, M., Orzechowski, M., Enache, O. M., Piccioni, F., Johnson, S. A., Lyons, N. J., Berger, A. H., Shamji, A. F., Brooks, A. N., Vrcic, A., Flynn, C., Rosains, J., Takeda, D. Y., Hu, R., Davison, D., Lamb, J., Ardlie, K., Hogstrom, L., Greenside, P., Gray, N. S., Clemons, P. A., Silver, S., Wu, X., Zhao, W. N., Read-Button, W., Wu, X., Haggarty, S. J., Ronco, L. V., Boehm, J. S., Schreiber, S. L., Doench, J. G., Bittker, J. A., Root, D. E., Wong, B., and Golub, T. R. (2017) A Next Generation Connectivity Map: L1000 Platform and the First 1,000,000 Profiles. Cell 171, 1437-1452 e1417

67. Neves, S. R., Ram, P. T., and lyengar, R. (2002) G Protein Pathways. Science 296, 16361639

68. Nilsson, J., Sengupta, J., Frank, J., and Nissen, P. (2004) Regulation of Eukaryotic Translation by the RACK1 Protein: A Platform for Signalling Molecules on the Ribosome. EMBO Rep. 5, 1137-1141

69. Lv, Q. L., Huang, Y. T., Wang, G. H., Liu, Y. L., Huang, J., Qu, Q., Sun, B., Hu, L., Cheng, L., Chen, S. H., and Zhou, H. H. (2016) Overexpression of RACK1 Promotes Metastasis by Enhancing Epithelial-Mesenchymal Transition and Predicts Poor Prognosis in Human Glioma. Int. J. Environ. Res. Public Health 13, 1021

70. Peng, R., Jiang, B., Ma, J., Ma, Z., Wan, X., Liu, H., Chen, Z., Cheng, Q., and Chen, R. (2013) Forced Downregulation of RACK1 Inhibits Glioma Development by Suppressing Src/Akt Signaling Activity. Oncol. Rep. 30, 2195-2202

71. Kim, J. H., Lee, S. M., Lee, J. H., Chun, S., Kang, B. H., Kwak, S., Roe, J. S., Kim, T. W., Kim, H., Kim, W. H., Cho, E. J., and Youn, H. D. (2015) OGFOD1 Is Required for Breast Cancer Cell Proliferation and Is Associated With Poor Prognosis in Breast Cancer. Oncotarget 6, 19528-19541

72. Okada, Y., Sonoshita, M., Kakizaki, F., Aoyama, N., Itatani, Y., Uegaki, M., Sakamoto, H., Kobayashi, T., Inoue, T., Kamba, T., Suzuki, A., Ogawa, O., and Taketo, M. M. (2017) Amino-Terminal Enhancer of Split Gene AES Encodes a Tumor and Metastasis Suppressor of Prostate Cancer. Cancer Sci. 108, 744-752 
73. Vives, V., Su, J., Zhong, S., Ratnayaka, I., Slee, E., Goldin, R., and Lu, X. (2006) ASPP2 Is a Haploinsufficient Tumor Suppressor That Cooperates With p53 to Suppress Tumor Growth. Genes Dev. 20, 1262-1267

74. Schenone, M., Dancik, V., Wagner, B. K., and Clemons, P. A. (2013) Target Identification and Mechanism of Action in Chemical Biology and Drug Discovery. Nat. Chem. Biol. 9, 232-240

75. Ong, S. E., Schenone, M., Margolin, A. A., Li, X., Do, K., Doud, M. K., Mani, D. R., Kuai, L., Wang, X., Wood, J. L., Tolliday, N. J., Koehler, A. N., Marcaurelle, L. A., Golub, T. R., Gould, R. J., Schreiber, S. L., and Carr, S. A. (2009) Identifying the Proteins to Which Small-Molecule Probes and Drugs Bind in Cells. Proc. Natl. Acad. Sci. U. S. A. 106, 46174622

76. Nijman, S. M. (2015) Functional Genomics to Uncover Drug Mechanism of Action. Nat. Chem. Biol. 11, 942-948

77. Lee, J., and Bogyo, M. (2013) Target Deconvolution Techniques in Modern Phenotypic Profiling. Curr. Opin. Chem. Biol. 17, 118-126

78. Kunimoto, R., Dimova, D., and Bajorath, J. (2017) Application of a New Scaffold Concept for Computational Target Deconvolution of Chemical Cancer Cell Line Screens. ACS Omega 2, 1463-1468

79. Keiser, M. J., Roth, B. L., Armbruster, B. N., Ernsberger, P., Irwin, J. J., and Shoichet, B. K. (2007) Relating Protein Pharmacology by Ligand Chemistry. Nat. Biotechnol. 25, 197206

80. Li, H., Gao, Z., Kang, L., Zhang, H., Yang, K., Yu, K., Luo, X., Zhu, W., Chen, K., Shen, J., Wang, X., and Jiang, H. (2006) TarFisDock: A Web Server for Identifying Drug Targets With Docking Approach. Nucleic Acids Res. 34, W219-224

81. Campillos, M., Kuhn, M., Gavin, A. C., Jensen, L. J., and Bork, P. (2008) Drug Target Identification Using Side-Effect Similarity. Science 321, 263-266

82. Liu, X., Baarsma, H. A., Thiam, C. H., Montrone, C., Brauner, B., Fobo, G., Heier, J. S., Duscha, S., Konigshoff, M., Angeli, V., Ruepp, A., and Campillos, M. (2016) Systematic Identification of Pharmacological Targets from Small-Molecule Phenotypic Screens. Cell Chem. Biol. 23, 1302-1313

83. Savitski, M. M., Reinhard, F. B., Franken, H., Werner, T., Savitski, M. F., Eberhard, D., Martinez Molina, D., Jafari, R., Dovega, R. B., Klaeger, S., Kuster, B., Nordlund, P., Bantscheff, M., and Drewes, G. (2014) Tracking Cancer Drugs in Living Cells by Thermal Profiling of the Proteome. Science 346, 1255784

84. Franken, H., Mathieson, T., Childs, D., Sweetman, G. M., Werner, T., Togel, I., Doce, C., Gade, S., Bantscheff, M., Drewes, G., Reinhard, F. B., Huber, W., and Savitski, M. M. (2015) Thermal Proteome Profiling for Unbiased Identification of Direct and Indirect Drug Targets Using Multiplexed Quantitative Mass Spectrometry. Nat. Protoc. 10, 1567-1593

85. Cox, J., and Mann, M. (2008) MaxQuant Enables High Peptide Identification Rates, Individualized P.P.B.-Range Mass Accuracies and Proteome-Wide Protein Quantification. Nat. Biotechnol. 26, 1367-1372

86. Szklarczyk, D., Morris, J. H., Cook, H., Kuhn, M., Wyder, S., Simonovic, M., Santos, A., Doncheva, N. T., Roth, A., Bork, P., Jensen, L. J., and von Mering, C. (2017) The STRING Database in 2017: Quality-Controlled Protein-Protein Association Networks, Made Broadly Accessible. Nucleic Acids Res. 45, D362-D368

87. Cianfrocco, M. A., DeSantis, M. E., Leschziner, A. E., and Reck-Peterson, S. L. (2015) Mechanism and Regulation of Cytoplasmic Dynein. Annu. Rev. Cell Dev. Biol. 31, 83-108

88. Yu, Y., and Feng, Y. M. (2010) The Role of Kinesin Family Proteins in Tumorigenesis and Progression: Potential Biomarkers and Molecular Targets for Cancer Therapy. Cancer 116, 5150-5160 
89. Eder, J., Sedrani, R., and Wiesmann, C. (2014) The Discovery of First-in-Class Drugs: Origins and Evolution. Nat. Rev. Drug Discovery 13, 577-587

90. Moffat, J. G., Vincent, F., Lee, J. A., Eder, J., and Prunotto, M. (2017) Opportunities and Challenges in Phenotypic Drug Discovery: An Industry Perspective. Nat. Rev. Drug Discovery 16, 531-543

91. Logsdon, D. P., Shah, F., Carta, F., Supuran, C. T., Kamocka, M., Jacobsen, M. H., Sandusky, G. E., Kelley, M. R., and Fishel, M. L. (2018) Blocking HIF signaling via novel inhibitors of CA9 and APE1/Ref-1 dramatically affects pancreatic cancer cell survival. Sci Rep 8, 13759

92. Zhang, Y., Steven, Laura, Caneda, C., Colton, Paul, Vogel, H., Gary, Michael, Li, G., John, Samuel, Lawrence, Edward, Gerald, Melanie, and Ben. (2016) Purification and Characterization of Progenitor and Mature Human Astrocytes Reveals Transcriptional and Functional Differences with Mouse. Neuron 89, 37-53

93. Sebaugh, J. L. (2011) Guidelines for Accurate EC50/IC50 Estimation. Pharm. Stat. 10, 128-134

94. Logsdon, D. P., Grimard, M., Luo, M., Shahda, S., Jiang, Y., Tong, Y., Yu, Z., Zyromski, N., Schipani, E., Carta, F., Supuran, C. T., Korc, M., Ivan, M., Kelley, M. R., and Fishel, M. L. (2016) Regulation of HIF1alpha under Hypoxia by APE1/Ref-1 Impacts CA9 Expression: Dual Targeting in Patient-Derived 3D Pancreatic Cancer Models. Mol Cancer Ther 15, 2722-2732

95. Cai, S., Wang, H., Bailey, B., Ernstberger, A., Juliar, B. E., Sinn, A. L., Chan, R. J., Jones, D. R., Mayo, L. D., Baluyut, A. R., Goebel, W. S., and Pollok, K. E. (2011) Humanized Bone Marrow Mouse Model as a Preclinical Tool to Assess Therapy-Mediated Hematotoxicity. 17, 2195-2206

96. The Cancer Genome Atlas Research Network. (2008) Comprehensive Genomic Characterization Defines Human Glioblastoma Genes and Core Pathways. Nature 455, 1061-1068

97. Grossman, R. L., Heath, A. P., Ferretti, V., Varmus, H. E., Lowy, D. R., Kibbe, W. A., and Staudt, L. M. (2016) Toward a Shared Vision for Cancer Genomic Data. N. Engl. J. Med. 375, 1109-1112

98. Dobin, A., Davis, C. A., Schlesinger, F., Drenkow, J., Zaleski, C., Jha, S., Batut, P., Chaisson, M., and Gingeras, T. R. (2013) STAR: Ultrafast Universal RNA-Seq Aligner. Bioinformatics 29, 15-21

99. Anders, S., Pyl, P. T., and Huber, W. (2015) HTSeq--A Python Framework to Work with High-Throughput Sequencing Data. Bioinformatics 31, 166-169

100. Robinson, M. D., McCarthy, D. J., and Smyth, G. K. (2010) edgeR: A Bioconductor Package for Differential Expression Analysis of Digital Gene Expression Data. Bioinformatics 26, 139-140

101. Lun, A. T., Chen, Y., and Smyth, G. K. (2016) It's DE-licious: A Recipe for Differential Expression Analyses of RNA-seq Experiments Using Quasi-Likelihood Methods in edgeR. Methods Mol. Biol. 1418, 391-416

102. UniProt Consortium. (2015) Uniprot: A Hub for Protein Information. Nucleic Acids Res. 43, D204-212

103. Smedley, D., Haider, S., Durinck, S., Pandini, L., Provero, P., Allen, J., Arnaiz, O., Awedh, M. H., Baldock, R., Barbiera, G., Bardou, P., Beck, T., Blake, A., Bonierbale, M., Brookes, A. J., Bucci, G., Buetti, I., Burge, S., Cabau, C., Carlson, J. W., Chelala, C., Chrysostomou, C., Cittaro, D., Collin, O., Cordova, R., Cutts, R. J., Dassi, E., Di Genova, A., Djari, A., Esposito, A., Estrella, H., Eyras, E., Fernandez-Banet, J., Forbes, S., Free, R. C., Fujisawa, T., Gadaleta, E., Garcia-Manteiga, J. M., Goodstein, D., Gray, K., GuerraAssuncao, J. A., Haggarty, B., Han, D. J., Han, B. W., Harris, T., Harshbarger, J., Hastings, R. K., Hayes, R. D., Hoede, C., Hu, S., Hu, Z. L., Hutchins, L., Kan, Z., Kawaji, H., Keliet, 
A., Kerhornou, A., Kim, S., Kinsella, R., Klopp, C., Kong, L., Lawson, D., Lazarevic, D., Lee, J. H., Letellier, T., Li, C. Y., Lio, P., Liu, C. J., Luo, J., Maass, A., Mariette, J., Maurel, T., Merella, S., Mohamed, A. M., Moreews, F., Nabihoudine, I., Ndegwa, N., Noirot, C., Perez-Llamas, C., Primig, M., Quattrone, A., Quesneville, H., Rambaldi, D., Reecy, J., Riba, M., Rosanoff, S., Saddiq, A. A., Salas, E., Sallou, O., Shepherd, R., Simon, R., Sperling, L., Spooner, W., Staines, D. M., Steinbach, D., Stone, K., Stupka, E., Teague, J. W., Dayem Ullah, A. Z., Wang, J., Ware, D., Wong-Erasmus, M., Youens-Clark, K., Zadissa, A., Zhang, S. J., and Kasprzyk, A. (2015) The BioMart Community Portal: An Innovative Alternative to Large, Centralized Data Repositories. Nucleic Acids Res. 43, W589-598

104. Cibulskis, K., Lawrence, M. S., Carter, S. L., Sivachenko, A., Jaffe, D., Sougnez, C., Gabriel, S., Meyerson, M., Lander, E. S., and Getz, G. (2013) Sensitive Detection of Somatic Point Mutations in Impure and Heterogeneous Cancer Samples. Nat. Biotechnol. 31, 213-219

105. Hagberg, A. A., Schult, D. A., and Swart, P. J. (2008) Exploring Network Structure, Dynamics, and Function Using NetworkX. in Proceedings of the 7th Python in Science Conference (SciPy2008) (Varoquaux, G., Vaught, T., and Millman, J. eds.), Pasadena, CA

106. Shannon, P., Markiel, A., Ozier, O., Baliga, N. S., Wang, J. T., Ramage, D., Amin, N., Schwikowski, B., and Ideker, T. (2003) Cytoscape: A Software Environment for Integrated Models of Biomolecular Interaction Networks. Genome Res. 13, 2498-2504

107. Halgren, T. (2007) New Method for Fast and Accurate Binding-site Identification and Analysis. Chemical biology \& drug design 69, 146-148

108. Halgren, T. A. (2009) Identifying and Characterizing Binding Sites and Assessing Druggability. J. Chem. Inf. Model. 49, 377-389

109. Baell, J. B., and Holloway, G. A. (2010) New Substructure Filters for Removal of Pan Assay Interference Compounds (PAINS) from Screening Libraries and for Their Exclusion in Bioassays. J. Med. Chem. 53, 2719-2740

110. Walters, W. P., Murcko, A. A., and Murcko, M. A. (1999) Recognizing Molecules with DrugLike Properties. Curr. Opin. Chem. Biol. 3, 384-387

111. Trott, O., and Olson, A. J. (2010) Autodock Vina: Improving the Speed and Accuracy of Docking with a New Scoring Function, Efficient Optimization, and Multithreading. Journal of computational chemistry 31, 455-461

112. Basavarajappa, H. D., Sulaiman, R. S., Qi, X., Shetty, T., Sheik Pran Babu, S., Sishtla, K. L., Lee, B., Quigley, J., Alkhairy, S., Briggs, C. M., Gupta, K., Tang, B., Shadmand, M., Grant, M. B., Boulton, M. E., Seo, S. Y., and Corson, T. W. (2017) Ferrochelatase Is a Therapeutic Target for Ocular Neovascularization. EMBO Mol. Med. 9, 786-801

113. Carpentier, G. (2012) Angiogenesis Analyzer for ImageJ.

114. Liao, Y., Smyth, G. K., and Shi, W. (2014) featureCounts: An Efficient General Purpose Program for Assigning Sequence Reads to Genomic Features. Bioinformatics 30, 923930

115. McCarthy, D. J., Chen, Y., and Smyth, G. K. (2012) Differential Expression Analysis of Multifactor Rna-seq Experiments with Respect to Biological Variation. Nucleic Acids Res. 40, 4288-4297

116. Dennis, G., Jr., Sherman, B. T., Hosack, D. A., Yang, J., Gao, W., Lane, H. C., and Lempicki, R. A. (2003) DAVID: Database for Annotation, Visualization, and Integrated Discovery. Genome Biol. 4, R60

117. Huang da, W., Sherman, B. T., and Lempicki, R. A. (2009) Systematic and Integrative Analysis of Large Gene Lists Using DAVID Bioinformatics Resources. Nat. Protoc. 4, 4457 
118. Mi, H., Muruganujan, A., Casagrande, J. T., and Thomas, P. D. (2013) Large-Scale Gene Function Analysis with the PANTHER Classification System. Nat. Protoc. 8, 1551-1566

119. Connelly, K. E., Hedrick, V., Paschoal Sobreira, T. J., Dykhuizen, E. C., and Aryal, U. K. (2018) Analysis of Human Nuclear Protein Complexes by Quantitative Mass Spectrometry Profiling. Proteomics 18, e1700427

120. Schwanhausser, B., Busse, D., Li, N., Dittmar, G., Schuchhardt, J., Wolf, J., Chen, W., and Selbach, M. (2011) Global Quantification of Mammalian Gene Expression Control. Nature 473, 337-342 
a

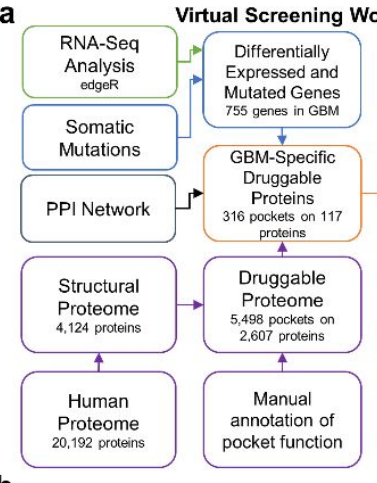

b

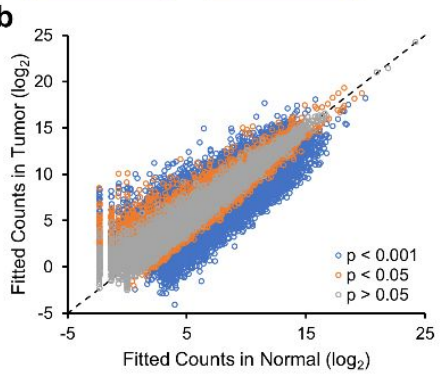

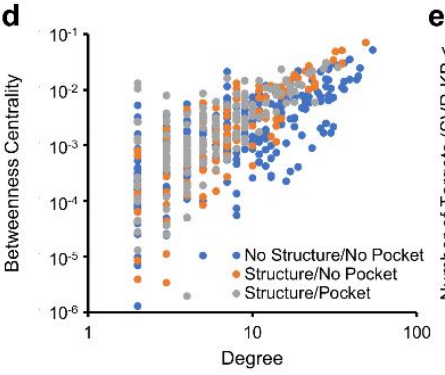

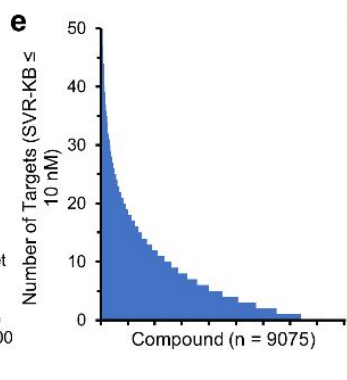

- 00000000000.0000 688000000.00800008

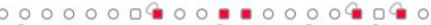

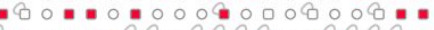

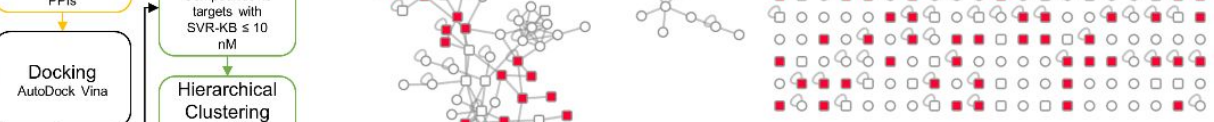

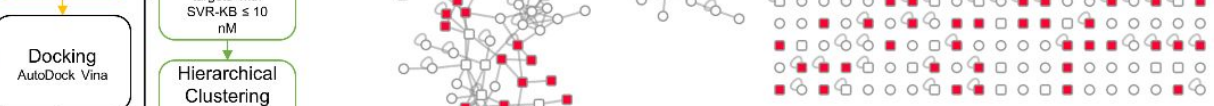

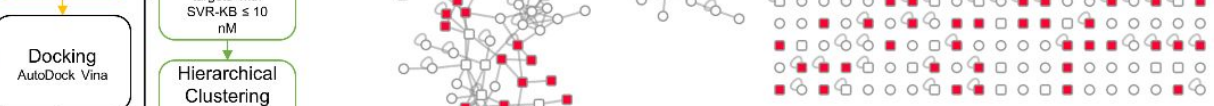

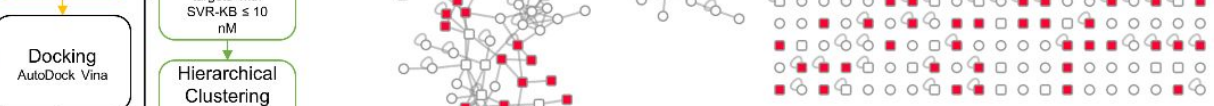
Clustering
Top 154
conpouns to
50 compounds
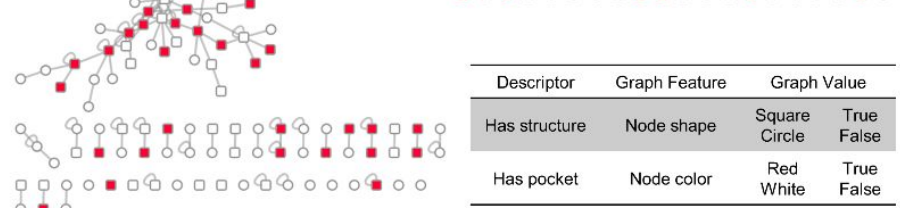

क \& \% :

$0000.08000088000 \% 00$

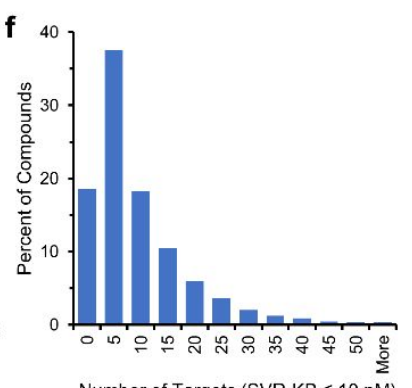

Number of Targets (SVR-KB $\leq 10 \mathrm{nM}$ )

Figure 1 

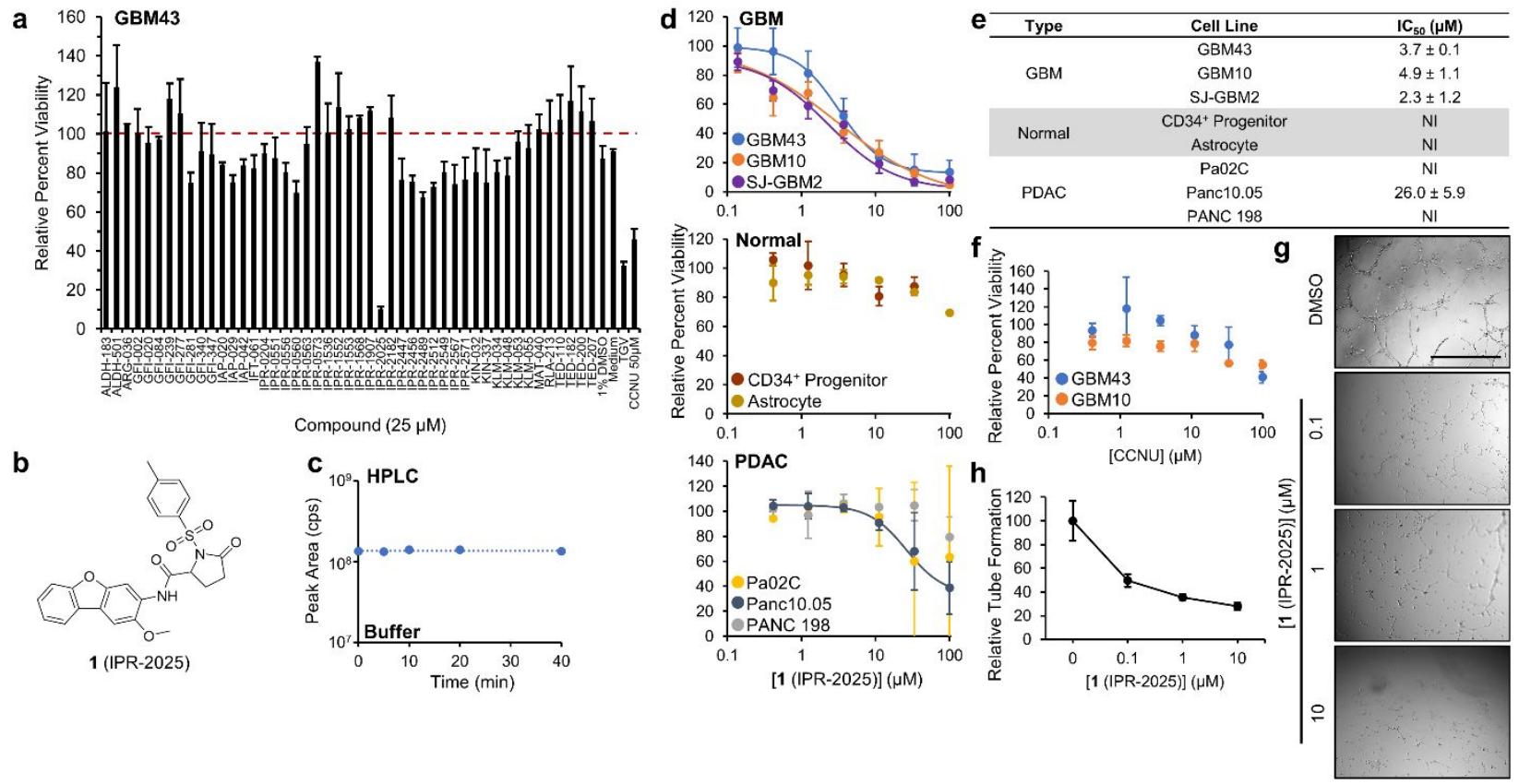

Figure 2

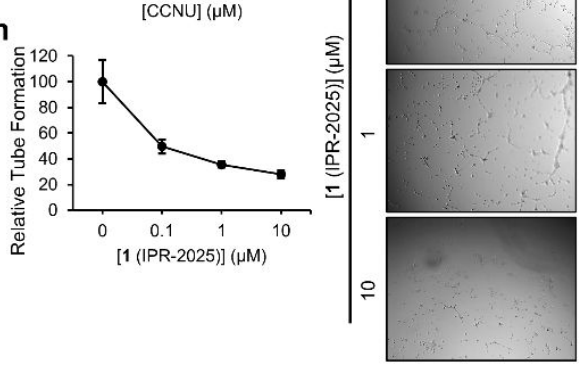




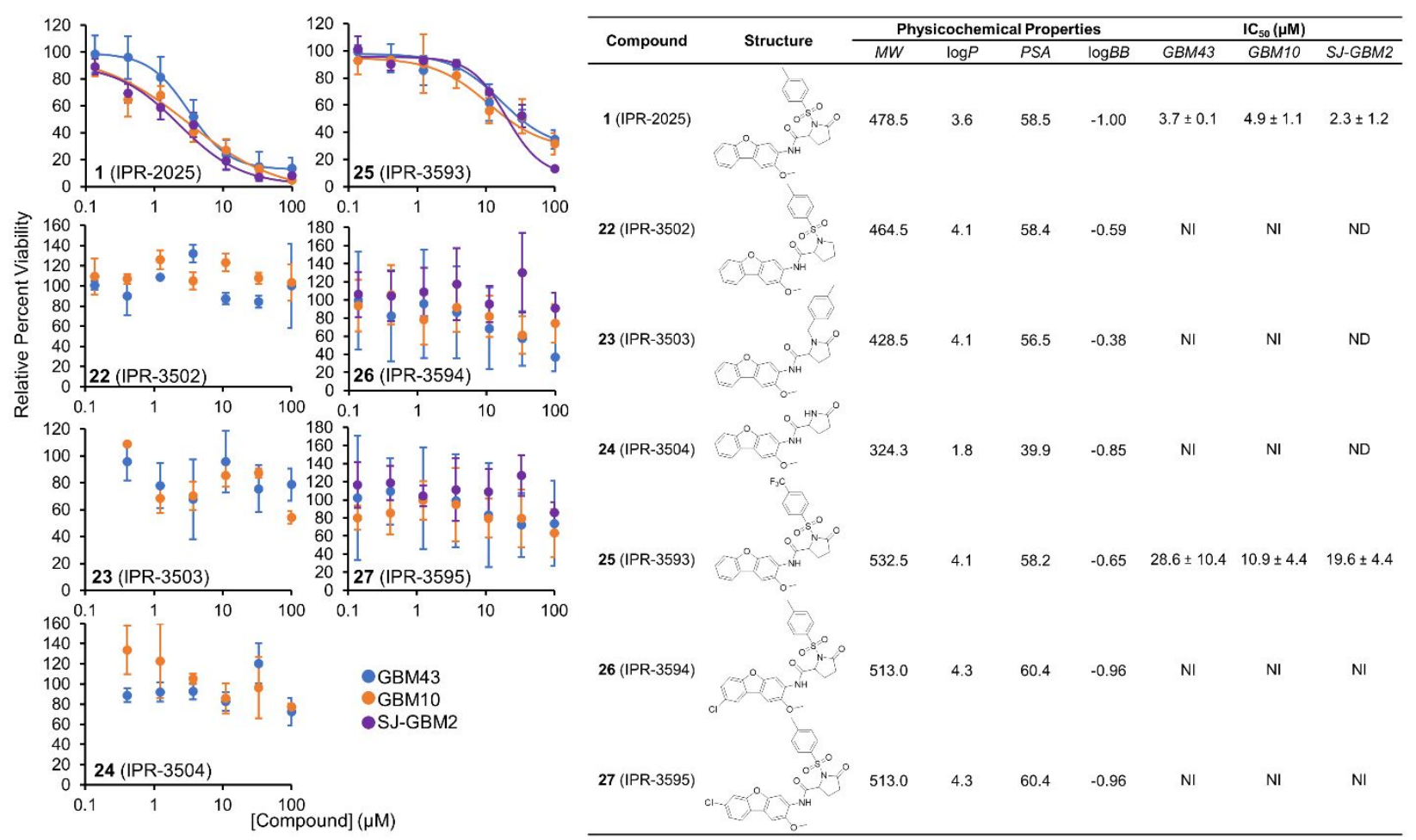

Figure 3 


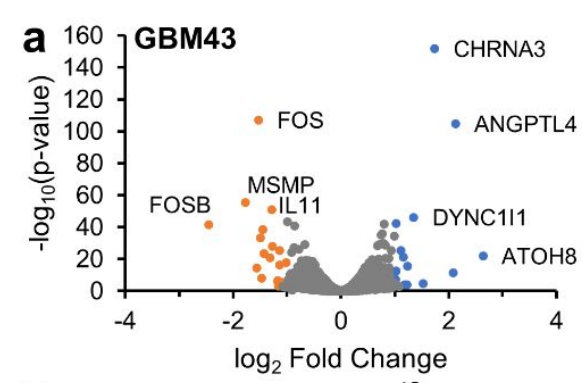

\section{b Most Overexpressed}

$\begin{array}{lllll}\text { Symbol Name } & \log _{2} \text { FC } \log \text { CPM } & \text { p-value } & \text { FDR }\end{array}$

\begin{tabular}{llcccc}
\hline Symbol & Name & $\log _{2}$ FC & $\log _{\text {CPM }}$ & p-value & FDR \\
\hline ATOH8 & Protein atonal homolog 8 & 2.6 & 0.4 & $1.2 \mathrm{E}-22$ & $5.9 \mathrm{E}-20$
\end{tabular}

$\begin{array}{llllll}\text { ANGPTL4 } & \text { Angiopoietin-related protein } 4 & 2.6 & 0.4 & 1.2 \mathrm{E}-22 & 5.9 \mathrm{E}-20 \\ & \text { ANG } & 2.1 & 4.9 & 1.8 \mathrm{E}-105 & 8.9 \mathrm{E}-102\end{array}$

$\begin{array}{llllll}\text { CHRNA3 Neuronal acetylcholine receptor subunit alpha-3 } & 1.7 & 5.5 & 1.8 \mathrm{E}-152 & 2.6 \mathrm{E}-148\end{array}$

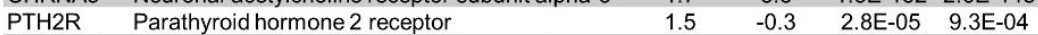

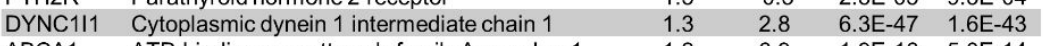

$\begin{array}{llllll}\text { ABCA1 } & \text { ATP-binding cassette sub-family A member } 1 & 1.2 & 6.9 & 1.9 \mathrm{E}-16 & 5.0 \mathrm{E}-14\end{array}$

$\begin{array}{llllll}\text { DLX5 Homeobox protein DLX-5 } & 1.2 & 1.4 & 3.8 \mathrm{E}-22 & 1.8 \mathrm{E}-19\end{array}$

\begin{tabular}{llllll} 
CYP1B1 Cytochrome P450 1B1 & 1.2 & 1.4 & $3.8 \mathrm{E}-22$ & $1.8 \mathrm{E}-19$ \\
\hline
\end{tabular}

$\begin{array}{llllll}\text { CYP1B1 } & \text { Cytochrome P450 1B1 } & 1.1 & 5.2 & 5.9 \mathrm{E}-26 & 3.2 \mathrm{E}-23 \\ \text { BMF } & \text { Bcl-2-modifying factor } & 1.0 & 2.7 & 3.4 \mathrm{E}-13 & 6.3 \mathrm{E}-11\end{array}$

$\begin{array}{lllll}\text { GATA2 Endothelial transcription factor GATA-2 } & 1.0 & 4.5 & 4.0 \mathrm{E}-43 & 7.3 \mathrm{E}-40\end{array}$

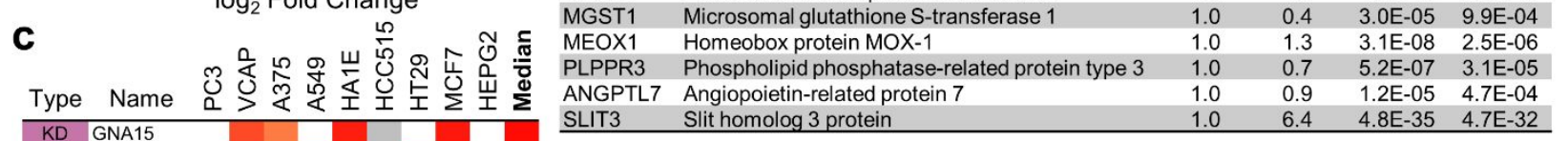

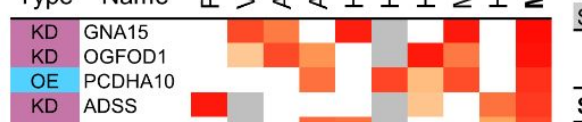

\section{Most Underexpressed}

\begin{tabular}{llcccc}
\hline Symbol & Name & $\log _{2}$ FC & $\log _{\text {CPM }}$ & p-value & FDR \\
\hline FOSB & Protein fosB & -2.4 & 1.5 & $2.1 \mathrm{E}-42$ & $3.0 \mathrm{E}-39$ \\
MSMP & Prostate-associated microseminoprotein & -1.8 & 6.8 & $3.0 \mathrm{E}-56$ & $1.1 \mathrm{E}-52$ \\
C1orf94 & Uncharacterized protein C1orf94 & -1.6 & 1.7 & $5.0 \mathrm{E}-15$ & $1.1 \mathrm{E}-12$ \\
FOS & Proto-oncogene c-Fos & -1.5 & 6.2 & $7.6 \mathrm{E}-108$ & $5.5 \mathrm{E}-104$ \\
SCN11A & Sodium channel protein type 11 subunit alpha & -1.5 & 1.6 & $3.5 \mathrm{E}-34$ & $3.2 \mathrm{E}-31$ \\
KDR & Vascular endothelial growth factor receptor 2 & -1.5 & 0.6 & $9.4 \mathrm{E}-09$ & $8.5 \mathrm{E}-07$ \\
SYTL5 & Synaptotagmin-like protein 5 & -1.4 & 4.6 & $2.3 \mathrm{E}-39$ & $2.9 \mathrm{E}-36$ \\
WISP1 & WNT1-inducible-signaling pathway protein 1 & -1.4 & 1.0 & $2.3 \mathrm{E}-24$ & $1.1 \mathrm{E}-21$ \\
KCNJ10 & ATP-sensitive inward rectifier potassium channel & -1.3 & 1.8 & $1.4 \mathrm{E}-21$ & $6.5 \mathrm{E}-19$ \\
& 10 & & & & \\
IL11 & Interleukin-11 & -1.3 & 4.6 & $8.4 \mathrm{E}-52$ & $2.5 \mathrm{E}-48$ \\
ARC & Activity-regulated cytoskeleton-associated protein & -1.3 & 2.4 & $6.6 \mathrm{E}-29$ & $4.4 \mathrm{E}-26$ \\
CALB1 & Calbindin & -1.2 & 0.9 & $1.3 \mathrm{E}-06$ & $7.1 \mathrm{E}-05$ \\
RASL10A & Ras-like protein family member 10A & -1.2 & 0.5 & $4.7 \mathrm{E}-04$ & $8.9 \mathrm{E}-03$ \\
DLL4 & Delta-like protein 4 & -1.1 & 1.8 & $3.3 \mathrm{E}-26$ & $1.9 \mathrm{E}-23$ \\
LFNG & Beta-1,3-N-acetylglucosaminyltransferase lunatic & -1.1 & 2.0 & $5.4 \mathrm{E}-17$ & $1.6 \mathrm{E}-14$ \\
& fringe & & & & \\
\hline
\end{tabular}

\section{Figure 4}




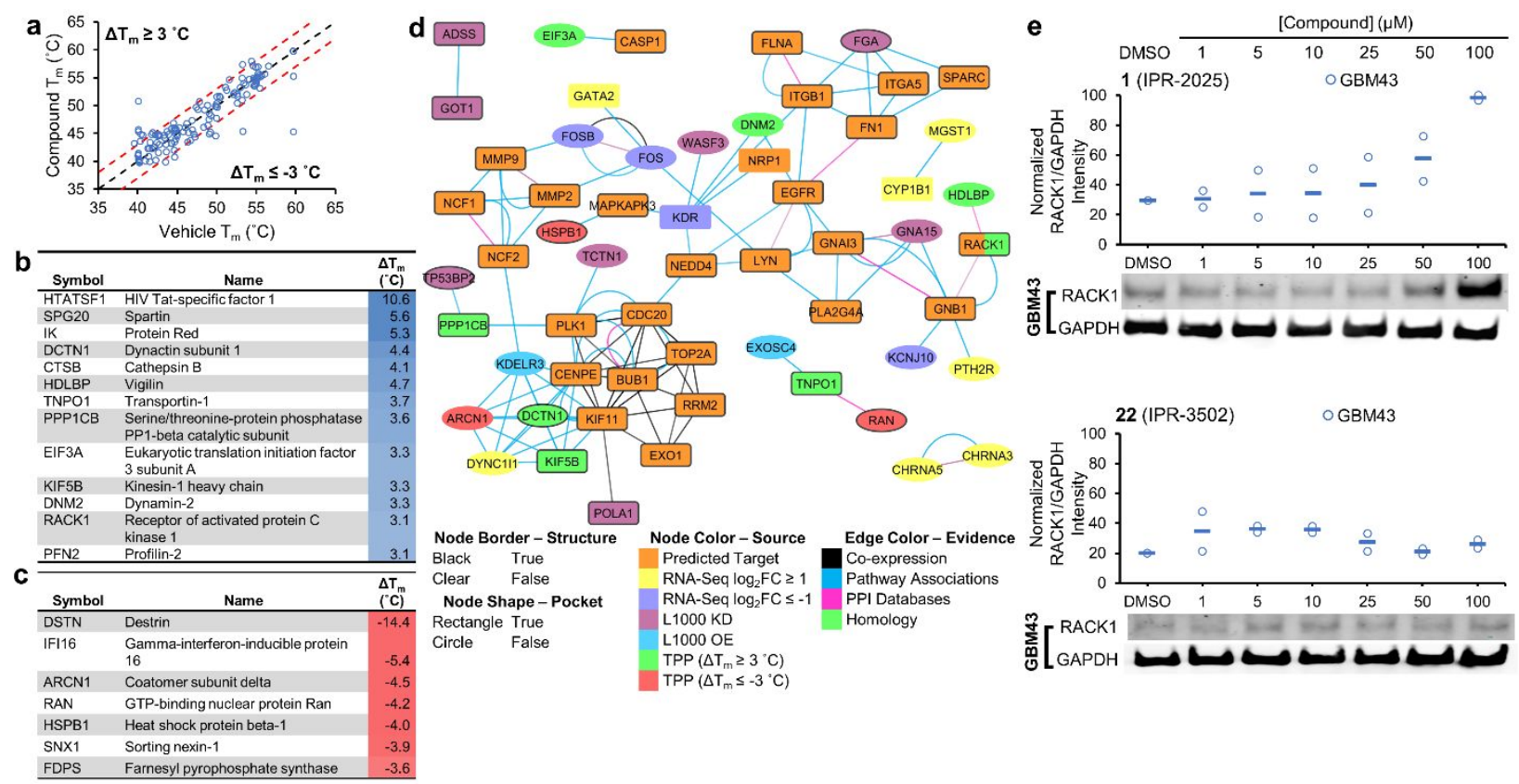

Figure 5 

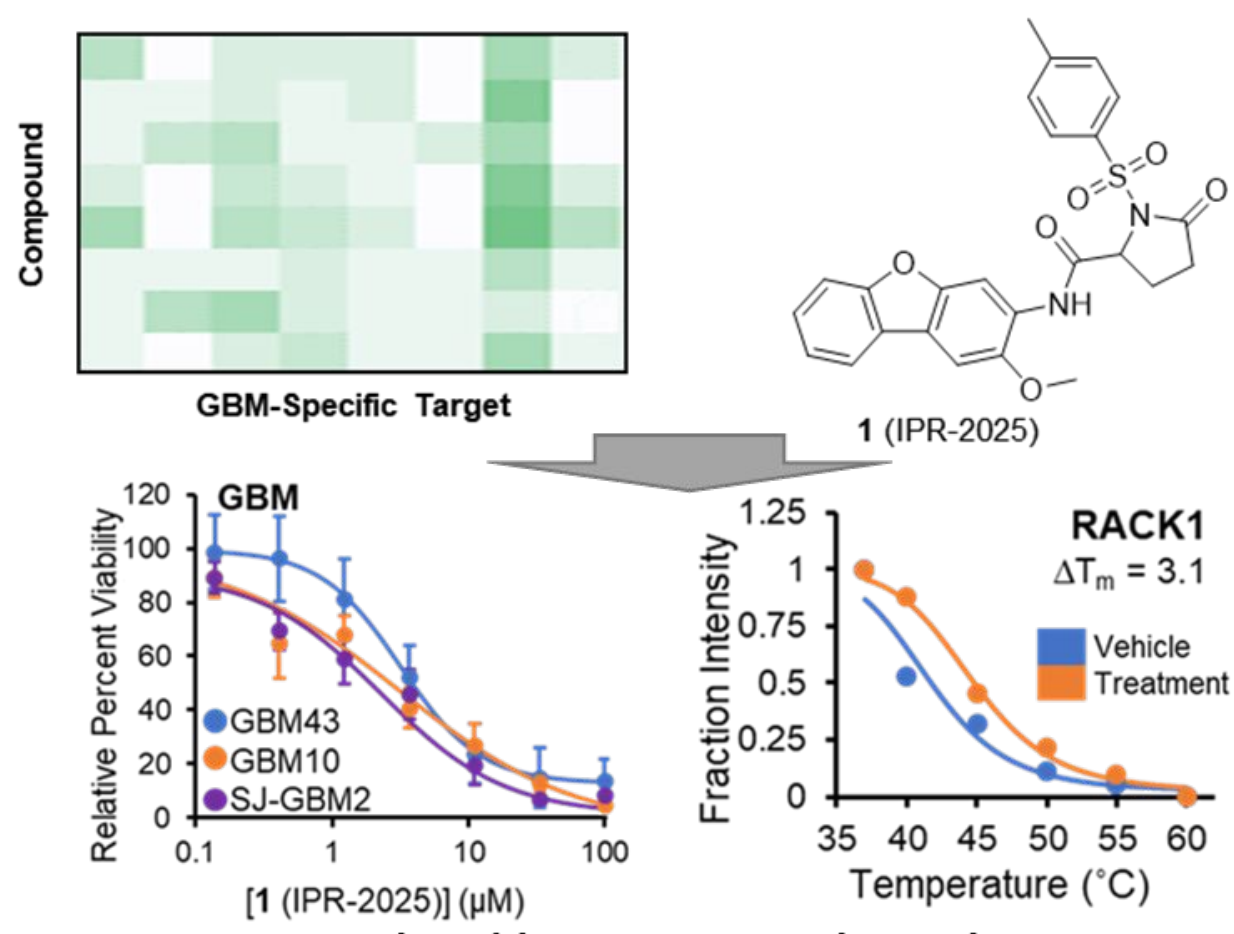

GBM Spheroid

Model

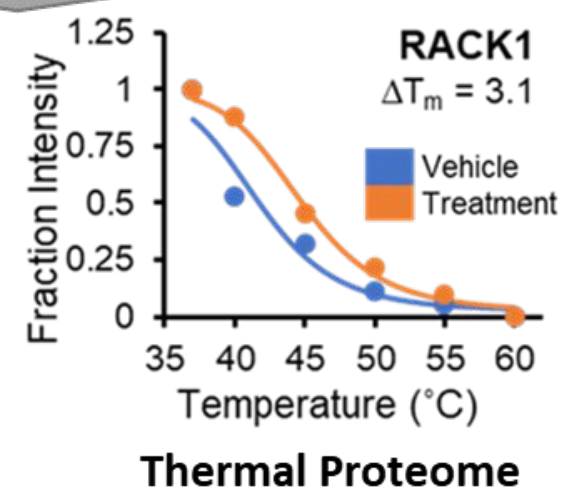

Profiling

TOC 